\title{
Change in Land Cover along the Lower Columbia River Estuary as Determined from Landsat Thematic Mapper (TM) Imagery
}

\section{Technical Report}

\section{3}

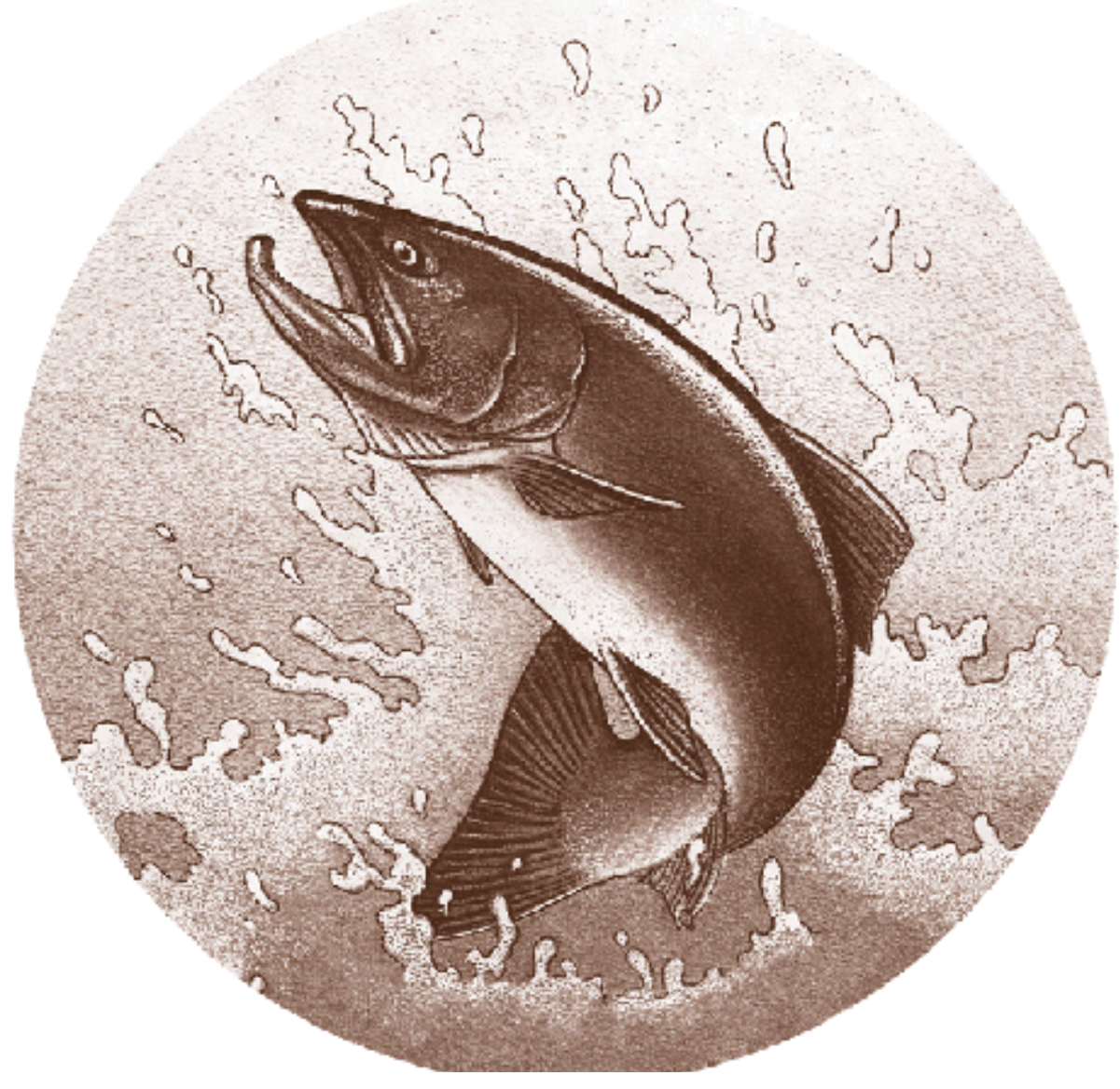

DOE/BP-00008768-4

October 2003 
This Document should be cited as follows:

Garono, Ralph, Becci Anderson, Rob Robinson, Charles Simenstad, "Change in Land Cover along the Lower Columbia River Estuary as Determined from Landsat Thematic

Mapper (TM) Imagery", Project No. 2002-01200, 42 electronic pages, (BPA Report

DOE/BP-00008768-4)

Bonneville Power Administration

P.O. Box 3621

Portland, Oregon 97208

This report was funded by the Bonneville Power Administration (BPA), U.S. Department of Energy, as part of BPA's program to protect, mitigate, and enhance fish and wildlife affected by the development and operation of hydroelectric facilities on the Columbia River and its tributaries. The views in this report are the author's and do not necessarily represent the views of BPA. 


\section{CHANGE IN LAND COVER \\ AlONG THE LOWER COLUMbia River EstuARY AS DETERMINED FROM LANDSAT TM IMAGERY}

\section{November 2003}

Submitted to

Bonneville Power Administration

US Army Corps of Engineers

Lower Columbia River Estuary Partnership

Submitted by

Ralph J. Garono, Becci Dale Anderson, \& Rob Robinson

in cooperation with

Charles Simenstad

Wetland Ecosystem Team, University of Washington
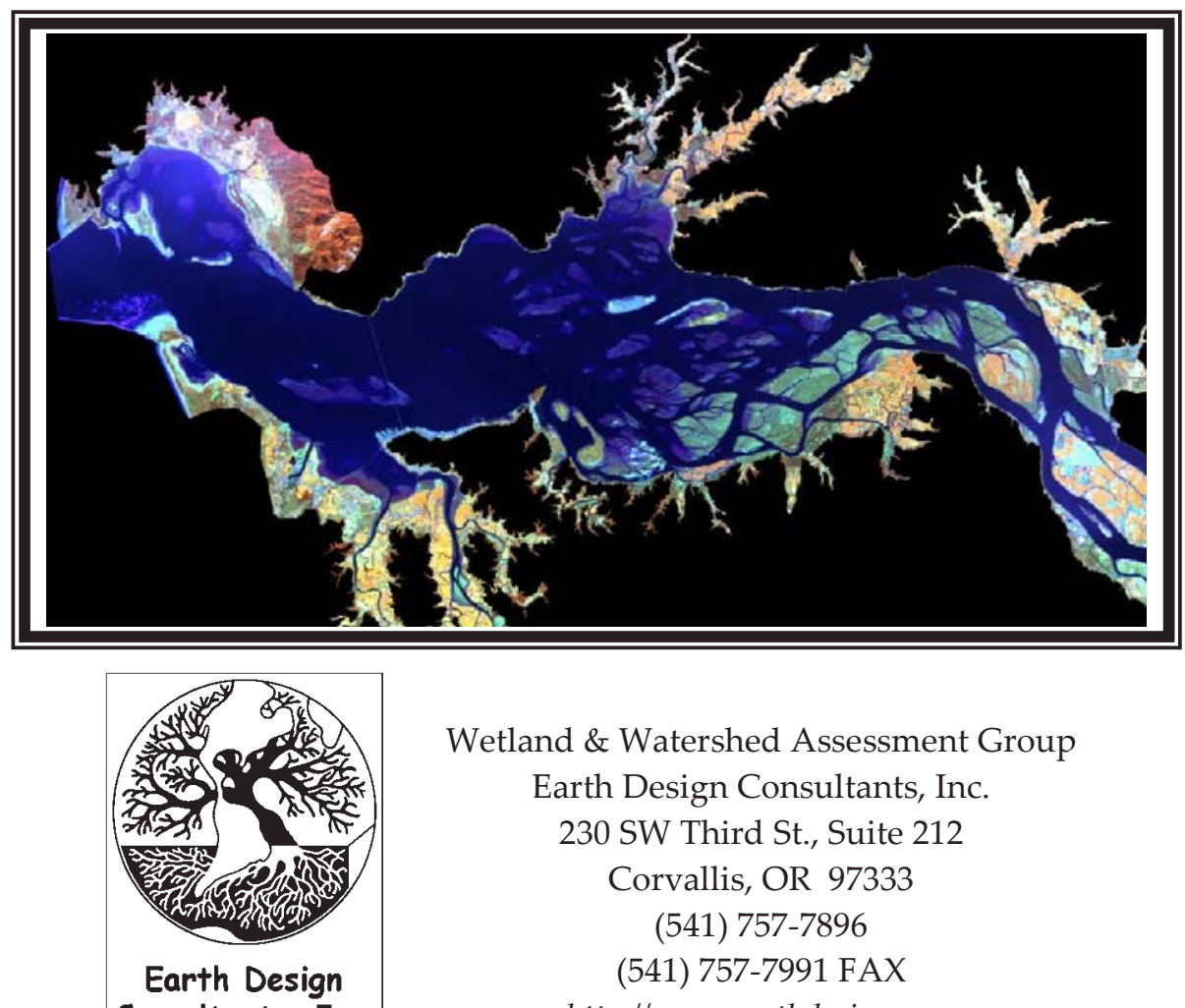

Wetland \& Watershed Assessment Group Earth Design Consultants, Inc.

230 SW Third St., Suite 212

Corvallis, OR 97333

(541) 757-7896

(541) 757-7991 FAX

Consultants, Inc. 


\section{TABLE OF CONTENTS}

INTRODUCTION

Background of the Estuary Partnership Habitat Mapping Project ....................................3

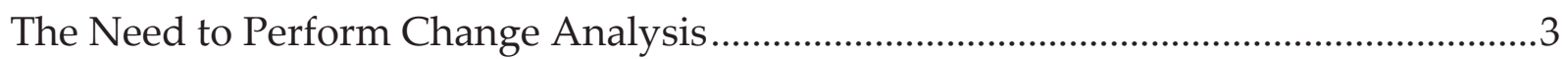

Change Analysis Overview..........................................................................................

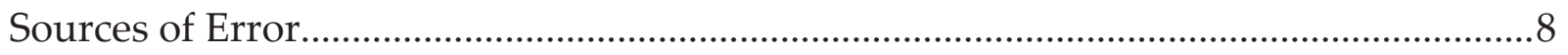

Data Sets Available for the Estuary Partnership Change Analysis Study .......................9

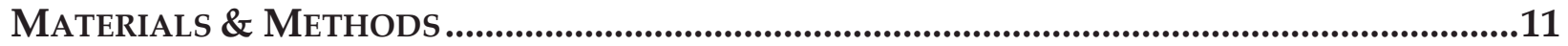

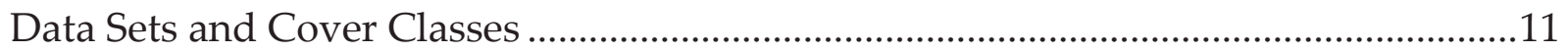

Coastal Change Analysis Program (TM1992)..............................................................11

Lower Columbia River Estuary Partnership (TM2000)..................................................12

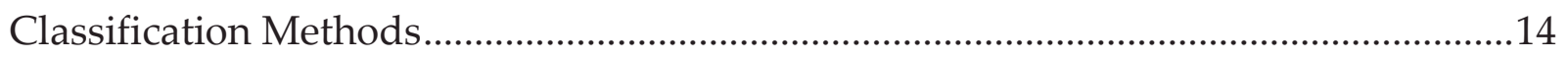

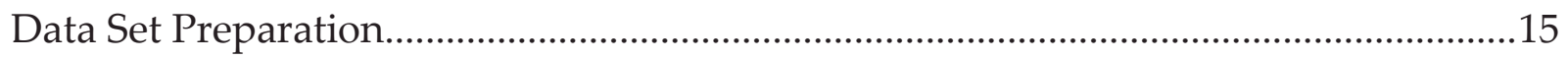

Change Analysis Methods ............................................................................................16

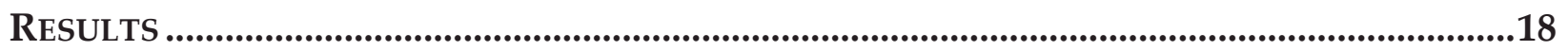

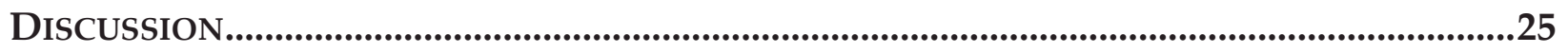

Interpreting the Cover Classes in the 1992-2000 Analysis................................................27

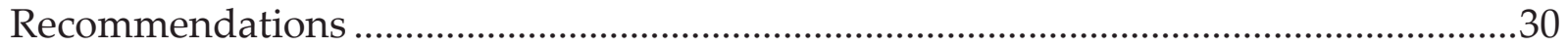

ACKNOWLEDGEMENTS ..........................................................................................................................33

LITERATURE CITED ...........................................................................................................................34

APPENDIX A. CROSSWALK BETWEEN SETS OF CLASSIFIED IMAGERY .........................................37

APPENDIX B. DESCRIPTION OF ClASSIFICATION SCHEME...........................................................38 


\section{INTRODUCTION}

\section{Background of the Estuary Partnership Habitat Mapping Project}

The Lower Columbia River Estuary Management Plan (Jerrick, 1991) recognizes the positive relationship between the conservation of fish and wildlife habitat, and sustaining their populations. An important component of fish and wildlife conservation and management is the identification of habitats, trends in habitat change, and delineation of habitat for preservation, restoration or enhancement. Alterations to the environment, such as hydropower generation, dredging, forestry, agriculture, channel alteration, diking, bank stabilization and floodplain development, have dramatically altered both the type and distribution of habitats along the Columbia River Estuary (CRE) and its floodplain. Along the Columbia River, tidally influenced habitats occur from the river mouth to the Bonneville Dam, a distance of $230 \mathrm{~km}$. If we are to effectively manage the natural resources of the Columbia River ecosystem, there is a need to understand how habitats have changed because fish and wildlife populations are known to respond to changes in habitat quality and distribution.

The goal of this study was to measure the amount and type of change of CRE land cover from 1992 to 2000. We performed a change analysis on two spatial data sets describing land cover along the lower portion of the estuary (Fig. 1). The 1992 data set was created by the NOAA Coastal Remote Sensing, Coastal Change Analysis Program (C-CAP) in cooperation with Columbia River Estuary Study Task Force (CREST), the National Marine Fisheries Service (NMFS) Point Adams Field Station, and State of Washington Department of Natural Resources (DNR). The 2000 data set was produced by Earth Design Consultants, Inc. (EDC) and the Wetland Ecosystem Team (WET: University of Washington) as part of a larger Lower Columbia River Estuary Partnership (Estuary Partnership) habitat mapping study. Although the image classification methodologies used to create the data sets differed, both data sets were produced by classifying Landsat Thematic Mapper (TM) satellite imagery, making it feasible to assess land cover changes between 1992 and 2000.

\section{The Need to Perform Change Analysis}

The Estuary Partnership mapping project was initiated in 2000 to produce a map of the current land cover classes along the CRE. The YR2000 project produced two spatial data sets, one created from Landsat 7 Enhanced Thematic Mapper (ETM+) satellite imagery and another created from high spatial resolution 19-Band airborne hyperspectral imagery (Garono et al., 2003a). From these data, the Estuary Partnership and its cooperators hoped to 1) develop indicators of "habitat health" and 


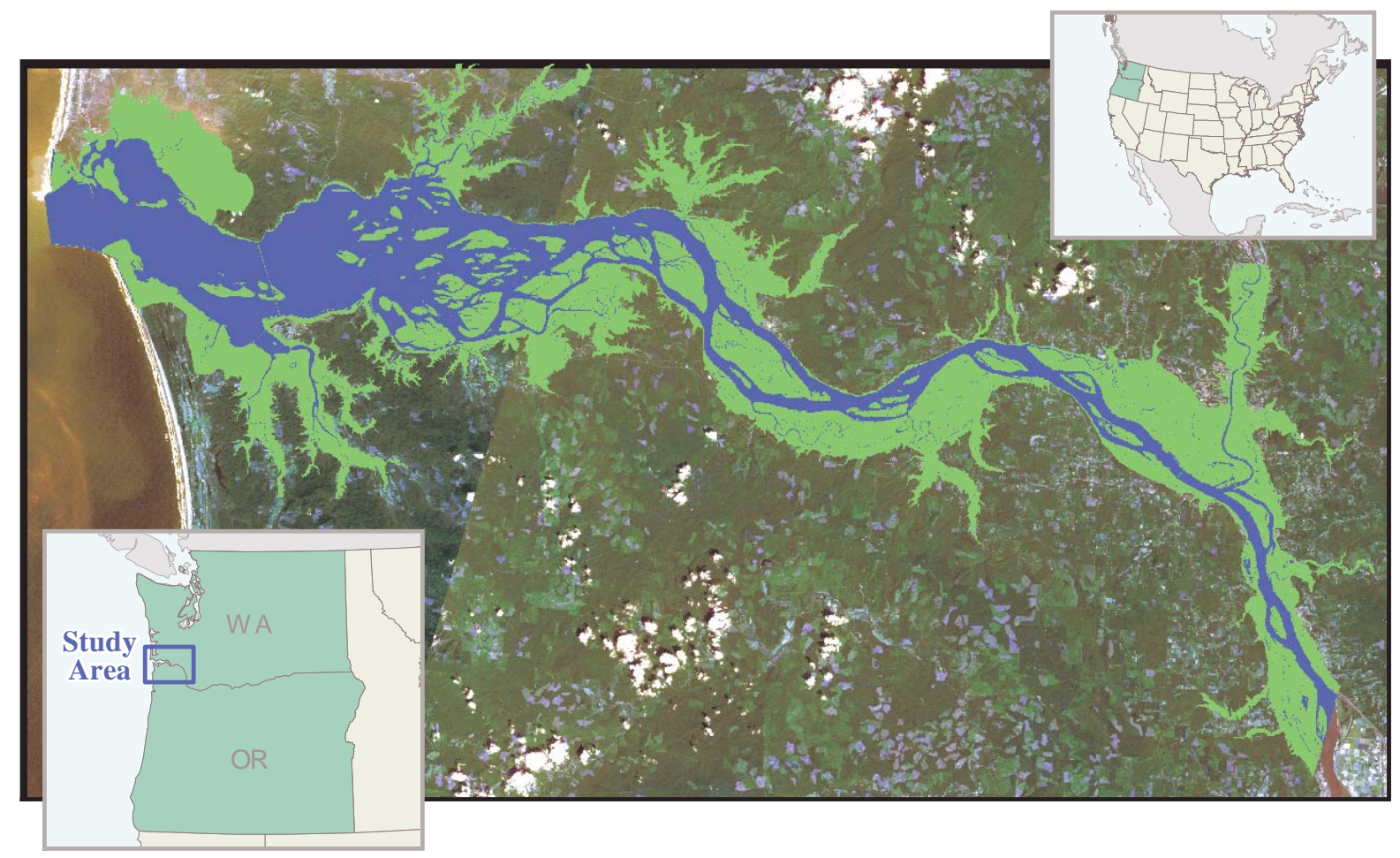

Figure 1: The change analysis study area (green and blue). The spatial extents of the two data sets differed. The extent of the 1992 imagery did not extend to Bonneville Dam although it did extend north to Willapa Bay and south to Tillamook Bay. The two YR2000 Landsat ETM + scenes covered the entire CRE (mouth to Bonneville Dam). Therefore, the spatial extent of this Change Analysis was limited to the region where these two data sets overlapped.

biological integrity, 2) develop definitions of "critical salmonid habitat", 3) evaluate tidal wetland restoration sites, 4) track exotic and invasive species, and 5) develop an understanding of how estuarine and riverine habitats have changed over the past 200 years. The change analysis presented in this report represented an important step in understanding how land cover classes along the Columbia River and its floodplain have changed during the late 1990s. We focused on the eight year interval between 1992 and 2000 because of the availability of the two data sets derived from Landsat satellite imagery. A similar change analysis study was completed by the NOAA C-CAP for the period of 1989 to 1992 . However, the 1992 C-CAP study summarized change in land cover over a much larger area than the current study, including upland forested areas. This forced the C-CAP study to use general land cover classes that are not specific to the habitats found in the CRE. For example, we found that the C-CAP land cover classification scheme considered many of the diked and periodically inundated tidal wetlands (e.g., channel islands) to be uplands. In the C-CAP study, the 1992 image was classified as a complete image using supervised and unsupervised classification; the 1989 land cover data set was derived through spectral change analysis (band

Earth Design Consultants, Inc.

(541) 757-7896 http://www.earthdesign.com 


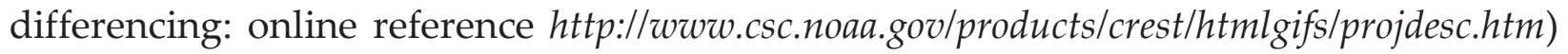
with the 1992 data set (only those pixels in the 1989 data set that differed from the 1992 data set were classified using supervised and unsupervised classification). Therefore, another important difference between the C-CAP study and the current study was that the C-CAP approach generated the change matrix on a pixel-by-pixel basis from only those pixels that changed in the two image sets. In contrast, the current study compared two fully classified satellite images. The next iteration of the NOAA C-CAP study is due to be released in the spring of 2004 (Burkhalter, 2003) and will measure change from 1992 to 2000 . However, the next C-CAP study is expected to use a generalized land cover class scheme not specific to the CRE. Therefore, the current study fills an important gap by focusing exclusively on estuarine and floodplain land cover classes.

In addition to the NOAA C-CAP studies, other groups are currently working to describe change in land cover along the CRE for other time intervals. NOAA-Fisheries and WET are collaborating to compare patterns in land cover from the late $19^{\text {th }}$ Century to 2000. The NOAA-Fisheries/ WET study will compare U.S. Coast and Geodetic Survey historic T-sheets from the first Columbia River surveys conducted from 1868 to 1901 to the EDC data sets derived from YR2000 Landsat 7 ETM+ and high resolution hyperspectral imagery.

Work presented in this report differs from the C-CAP and NOAA-Fisheries/ WET studies in two respects. First, it differs from the C-CAP study by comparing land cover classes only within the river and its adjacent floodplain (Fig. 1) using a land cover classification scheme that was tailored specifically to riverine and estuarine environments. Specifically, the classification scheme included the identification of diked areas. Second, this study differed from both the T-sheet and C-CAP studies in that it compared results from two similar data sets, i.e., both data sets were derived from satellite data classified as a whole.

\section{Change Analysis Overview}

The term "change analysis" refers methods of summarizing change in spatial data sets. There are numerous methods for conducting a change analysis, and the following discussion is a brief overview. Generally, spatial data sets that are used in a change analysis are raster (grid) data sets. The grid is composed of cells, also referred to as pixels. Each cell corresponds to a known area on the ground. For Landsat 7 TM data, the area on the ground represented by a pixel is about $30 \times 30-\mathrm{m}$. Hence, Landsat 7 TM data are often described as having $30-\mathrm{m}$ pixels. Change analysis involves tabulating the difference between two spatial data sets at different time periods to reveal how areas of 
interest have changed over time. Change analysis is often used to detect conversion from one type of land cover to another. It can also be used to track alterations in specific land cover categories only, such as natural or manmade structures (i.e., shorelines, channels, building footprints, etc.), and can be measured as change in area or length ${ }^{1}$. Change can also be measured at the landscape scale as alterations in the distribution or size of habitat patches.

A common type of change analysis is performed by subtracting one image data set from another to isolate only areas of change. Typically, this type of analysis does not require a classified image; however, it requires knowledge of the features that have changed and knowledge of the agent of change. This method is used most commonly when there is only one land cover class of interest, such as vegetation, that is expected to change to another land cover class. For example, if one wanted to measure the area burned by a forest fire, the extent of a fire could be determined by subtracting the image of the burned region from an earlier image taken before the region was burned. While this technique is useful in tracking change in one land cover class, it is not useful in tracking change between multiple land cover classes. A more sophisticated type of change analysis would be necessary if one cover class, herbaceous wetland for example, could change to shrub-scrub, bare, urban, or upland, depending on the circumstances. Change analysis involving multiple land cover classes generally requires a classified data set, in which individual cells have been assigned a unique land cover class during the classification procedure. In this report, we will focus on this second method of change analysis, looking specifically for changes among multiple land cover classes.

One way to monitor change in landscapes is by examining the change in area of each cover class from one time step to the next. Yet, a more descriptive way to summarize change is to record how much of each cover class changes, and into which cover class it changes. In this type of change analysis, referred to here as a crosstabulation, the two data sets are analyzed by tracking the value for each raster cell from its initial to its final value. The initial value is referred to as the "from" value and the final value as the "to" value. "From" and "to" values are then totaled in a matrix that lists the cover classes from the initial data set as rows and the cover classes from the final data set as columns. In Figure 2, the number of cells in each cover class was converted to hectares and recorded in the boxes of the matrix. Row totals, shown in Figure 2 in blue, are the number of hectares in the "from" data set for each cover class. Column totals, shown in

\footnotetext{
${ }^{1}$ Typically, change detection of shorelines or channels is performed using photointerpretation techniques. This differs from image classification in that photointerpretation requires the user to identify each feature where image classification relies on computer algorithms to identify features. Sometimes, however, features can be identified in imagery and conventional photo-interpretive techniques employed.
}

Earth Design Consultants, Inc. 
Figure 2 in orange, represent the total number of hectares for the "to" data set for each cover class.

The change matrix aids in interpreting the transformations that occurred, as well as analyzing how much of the area did not change. In the Figure 2 example, there are 172 total hectares in the forest class in the initial data set. In the final data set, only 130 hectares that were forest in the initial data set remain classified as forest. Thirty hectares that were forest in the initial data set changed to water and 12 hectares changed from forest to urban. Also, 20 hectares that were water in the initial data set are forest in the final data set, as well as 10 hectares that were urban and are forest in the final data set. The redistribution of area in classes results in approximately a $-6 \%$ decrease from 170 hectares of forest in the initial image to 160 hectares of forest in the final image. Therefore, a change matrix provides more insight into the type of loss or gain of each cover class than reporting change as simply the change in area of each cover class. A change matrix also identifies the cover classes that are rapidly changing. In Figure 2, most cells ( 76\%) of the "from" data set remained as forest when it was remeasured indicating three-fourths of the pixels did not change during the time interval.

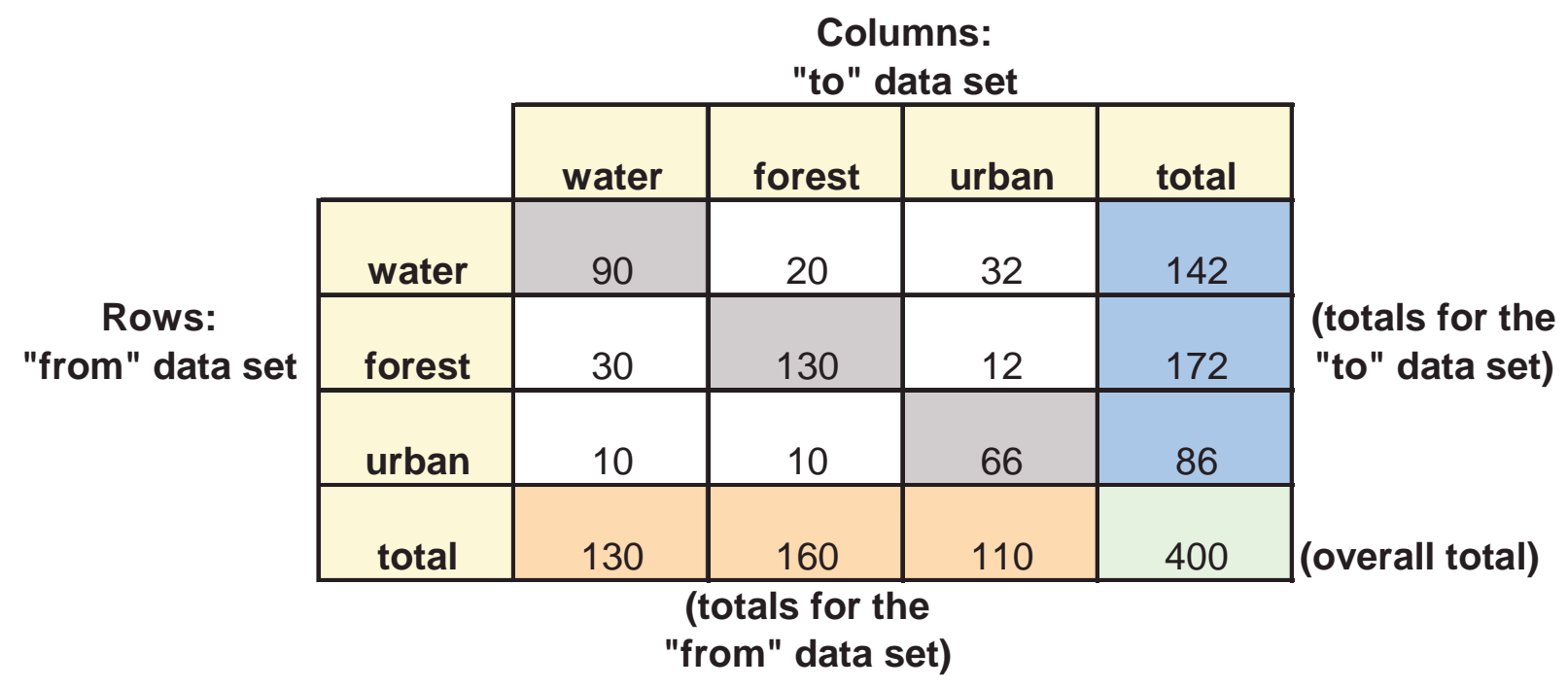

Figure 2: Example of a hypothetical change matrix. The number hectares for each cover class are shown in the boxes. The total to the right of each row (blue) is the total number of hectares in the "from" data set for that given class. The total at the bottom of each column (orange) represents the total hectares for the "to" data set for that given class. 


\section{Sources of Error}

Although the example above implies that there is a real $-6 \%$ decrease in forest, this decrease could also have been created by inaccuracies in the data sets. For this reason, it is important to understand the sources of error that may be present in each of the data sets used in an analysis. Data sets that are selected for a change analysis must meet certain criteria with regard to spatial scale, spatial extent, spatial error and classification scheme.

The data sets must be at the same or similar spatial scale. Spatial scale is a measure of data accuracy and precision, and implies how much information is contained in the data. The larger (finer) the geographic scale is, the more information that can be contained in the data. The smaller (more coarse) the geographic scale is, the more generalized the data often are. Spatial scale also affects the level of habitat classification. Larger scale data are more accurate and precise, that is, mapped features will be represented closer to their true ground locations. Another consideration is that data sets at different scales often map entirely different ground features. For example, a data set at a very large spatial scale might map the location of individual trees, whereas small scale data may only be accurate enough to map the area as a forest. As previously mentioned, the pixels that make up the classified image can only belong to one cover class. Areas that are naturally complex can be represented as either single cover classes or multiple cover classes. For example, a predominately forested area may have wetland, shrub-scrub, or even bare areas included within it. With larger scale data it may be possible to resolve many of these embedded patches as discrete cover classes; however, with smaller scale data, many patches may be lost and the pixels assigned to values of the dominant land cover. Therefore, subtle changes in the vegetation composition underlying the location of a pixel can influence the cover class to which that pixel is assigned during the classification process. Thus, spatial scale is related to the size, or resolution, of the raster grid cells used in this type of change analysis. The raster grid cells must be exactly the same size for the change analysis to be performed.

Spatial error and spatial extent should also be similar in both data sets used in the change analysis. Spatial error, a measure of positional accuracy, provides a determination of how accurate mapped features are to their real-world locations. The cover class to which a pixel is assigned during the classification process can be affected by the spatial error. For example, the spatial error reported by Garono et al. (2003b) for classification of two Landsat $7 \mathrm{ETM}+$ scenes were 0.31 and 0.45 pixels, representing an on the ground distance of 9.3 to $13.5-\mathrm{m}$, respectively. A $10-\mathrm{m}$ shift in the area that a pixel covers can, in some circumstances (see discussion above), influence the cover class to which that pixel is assigned during the classification process. Therefore, spatial error 
can affect the results of the change analysis. For this reason, data sets used in a change analysis are required to have similar spatial error to ensure that the change tracking of the land cover class is true. Spatial extent is the geographic coverage of the data set. Because the images are compared on a grid cell by grid cell basis, the data sets must also have a common spatial extent.

The set of cover classes that describe features in the data set is known as the classification scheme. The classification scheme must be similar in both data sets to evaluate change in a meaningful way. If the classification schemes are not the same, often they can be made more similar through the process of cross-walking. Crosswalking is the process of matching up similar cover classes from the two data sets. Often, the number of cover classes is reduced during the cross-walking procedure because cover classes in one data set must be combined if corresponding classes do not exist in the other data set. For example, if one data set mapped deciduous and coniferous forests and the second only mapped forests, the two classes in the first data set would have to be combined into a common 'forest class' so that the change could be determined. Therefore, the change in deciduous and/or coniferous forest classes could not be measured in this hypothetical change analysis using the cross-walked data.

\section{Data Sets Available for the Estuary Partnership Change Analysis Study}

There were several data sets available for use in this study. Previous studies have produced data sets describing land cover classes for portions of the CRE (Thomas, 1980; Thomas, 1983; Graves et al., 1995; NOAA, 1997; Allen, 1999); however, these studies used multiple and varied data sources, and differed in spatial extent, spatial scale, classification schema and methodology.

In the early 1990's several federal agencies formed a consortium to share the costs associated with the acquisition of satellite images for their environmental monitoring programs. Original members of the Multi-Resolution Land Characteristics (MRLC) consortium were the U.S. Geological Survey (USGS), Environmental Protection Agency (EPA), National Oceanic and Atmospheric Administration (NOAA) and the U.S. Forest Service (USFS). The National Atmospheric and Space Administration (NASA) and the Bureau of Land Management (BLM) joined the consortium later.

The MRLC produced several satellite-based mapping products covering large expanses of the U.S. including the: (1) Coastal Change Analysis Project (C-CAP) administered by NOAA; (2) Gap Analysis Project (GAP) directed by the Biological Resources Division of the USGS; and the National Land Cover Data (NLCD) project directed by both the 
USGS and EPA. The data produced by these projects are readily available (www.epa.gov/mrlc).

We evaluated the following data sets derived from Landsat TM imagery, for use as the "from" data for this project:

- The Gap Analysis Project (GAP) is directed by the Biological Resources Division of the U.S. Geological Survey. The GAP project strives to "keep common species common" by identifying areas where native species are not adequately represented and detecting areas of fragmentation in the natural environment. The GAP data set for Oregon was completed in 1998. This raster data set has a spatial extent that covers the state of Oregon and a spatial resolution of 30 meter grid cells (approximately 1:100,000 scale). The Anderson classification scheme (Anderson et al., 1975) was used in the creation of this data set, and includes 63 cover classes. More information on this data set is available from http://www.gap.uidaho.edu/.

- The National Land Cover Data (NLCD) includes partners from the U.S. Geological Survey, U.S. Environmental Protection Agency, U.S. Forest Service, and National Oceanic and Atmospheric Administration. The NLCD project exists for the sole purpose of creating a nationally consistent land cover data set. The first NLCD was released in 1992 and was created by classifying Landsat Thematic Mapper imagery from the early to mid-1990s. The 21-class land cover scheme used in this data set was developed by the NLCD to be used over the entire United States, and includes 21 cover classes. The spatial extent of this data set is the contiguous United States, and the spatial resolution is 30 meter grid cells (approximately 1:100,000 scale). The NLCD data set is being produced again for 2001 imagery, and is due to be released in 2004. More information can be found at http://landcover.usgs.gov/nationallandcover.html.

- Coastal Change Analysis Project (C-CAP) is administered by NOAA's Coastal Change Analysis Program. C-CAP's primary function is to further the creation and dispersal of regional landscape cover and change analysis data throughout the US coastal zone, using remote sensing technologies. C-CAP interprets, categorizes, and integrates remotely sensed data, aerial photography, and field data with other data sets in a Geographic Information System (GIS) to inventory coastal submersed habitats, wetland habitats, and adjacent uplands (TM1992 metadataTM1992.htm). In 1992, the Coastal Change Analysis Program (C-CAP) initiated a change analysis study on the lower Columbia River, comparing classified Landsat Thematic Mapper data from 1989 and 1992. These two data sets have a resolution of 30 meter cells (approximately 1:100,000 scale) and a spatial extent of the lower Columbia River estuary. The C-CAP classification scheme is a modification of the Klemas et al. (1993) classification scheme, and was designed to be compatible with the classification systems used by the USGS, U.S. Fish and Wildlife Service, and U.S. EPA. It contains 15 cover classes. The C-CAP program for the lower Columbia River is currently being repeated and data is due to be available in spring 2004 (Burkhalter, 2003). More information is available at http://www.csc.noaa.gov/crs/ccap_index.html.

Of these, we chose to work with the C-CAP data for the "from" data set because it depicted land cover for the mouth of the Columbia River and it was developed as part

Earth Design Consultants, Inc.

(541) 757-7896 http://www.earthdesign.com 
of a regular coastal change analysis program. We selected the TM2000 classified imagery as the "to" data. The TM2000 imagery was derived from classified Landsat 7 ETM+ imagery and focused on river and adjacent floodplain habitat cover classes: this data set was developed specifically for the Estuary Partnership.

\section{MATERIAls \& MeThODS}

\section{Data Sets and Cover Classes}

\section{Coastal Change Analysis Program (TM1992)}

We selected a classified Landsat 7 TM scene, acquired in 1992 by C-CAP, as the "from" data set. In this report it is referred to as TM1992. The TM sensor detects radiation reflected from the surface of the earth in 7 discrete bands (an eighth band was added to the Landsat 7 ETM+ sensor). Band $1(0.45-0.52 \mu)$, band $2(0.52-0.60 \mu)$, band $3(0.63-$ $0.69 \mu)$ and band $4(0.76-0.90 \mu)$ are in the visible spectrum; band $5(1.55-1.75 \mu)$ and band $7(2.08-2.35 \mu)$ are in the mid-infrared; and, band $6(10.4-12.5 \mu)$ is thermal (http://eosims.cr.usgs.gov: 5725/DATASET DOCS/ landsat7 dataset.html). Typically, bands in the visible and infrared portions of the spectrum are used in classifying vegetation. The TM1992 data set is a classified remote sensing image that is a part of the Columbia River Estuary Change Detection Project published by the Coastal Change and Analysis program (C-CAP) in Charleston, South Carolina in 1996 (NOAA Coastal Services Center, 1997). NOAA C-CAP is continually developing a "nationally standardized database of land cover and habitat change in the coastal regions of the United States" (NOAA Coastal Change Analysis Program). The TM1992 data set is as current as the date of the Landsat scene (1992) and is considered to be complete with no update planned (NOAA Coastal Services Center, 1997).

We selected the C-CAP data because of its similarities with the "to" data set (TM2000) in data type, spatial extent, and classification scheme. We chose the 1992 C-CAP data set rather than the 1989 C-CAP data set because different sections of the 1989 imagery were classified using different methods and the C-CAP program has already performed the change analysis comparing the data from 1989 to 1992. The C-CAP change detection was completed for an area much larger than the current study (i.e., it did not focus on the estuary): C-CAP study results were largely influenced by the forested, shrub-scrub, and grassland areas (Table 1). The focus of the current study was the estuary and its tidally-influenced floodplain. We were interested in detecting the change that has occurred since the completion of 1989-1992 C-CAP study, the interval from 1992 to 2000. 


\begin{tabular}{|c|c|}
\hline & \\
\hline Developed High Intensity & $2,168.0$ \\
\hline Developed Low Intensity & $3,673.1$ \\
\hline Grassland & $15,957.0$ \\
\hline Cultivated Land & 45.9 \\
\hline Evergreen Forest & $4,107.3$ \\
\hline Shrub-Scrub & $11,694.2$ \\
\hline Bare Land & $2,337.3$ \\
\hline Estuarine Emergent & $2,283.6$ \\
\hline Palustrine Emergent & $4,648.9$ \\
\hline Palustrine Scrub & $7,099.9$ \\
\hline Palustrine Forest & $4,388.0$ \\
\hline Water & $41,585.1$ \\
\hline Unconsolidated Shore & $6,852.8$ \\
\hline Mixed Forest & $4,191.3$ \\
\hline Deciduous Forest & $1,269.7$ \\
\hline
\end{tabular}

Lower Columbia River Estuary Partnership (TM2000)

The "from" data set was created by Earth Design Consultants, Inc. (EDC) for the Estuary Partnership as part of a larger habitat mapping project (Garono et al., 2003b; Garono et al., 2003a). It is a classified Landsat 7 ETM+ scene (47/28) acquired on March 24, 2000, and will be referred to as the TM2000 data set. Although two Landsat 7 ETM+ scenes were classified in the EDC study (Garono et al., 2003b), we selected only the western portion of the TM2000 data set for this change analysis because comparable CCAP data only exist in this area (Fig. 1). The entire TM2000 data set describes the distribution of land cover classes along the lower Columbia River and floodplain, from the mouth to Bonneville Dam.

The classification scheme created for the TM2000 data set was developed with input from a diverse group of stakeholders and was tailored to the land cover classes of the CRE. Cover classes were meant to focus specifically on estuarine and tidal freshwater habitats. In particular, we were interested in differentiating between areas which were tidally influenced from those that were not including, areas where only muted tidal exchange may occur. Twenty-six cover classes were identified from the Landsat 7 
ETM+ imagery (Table 2). Fourteen cover classes were identified, using a combination of unsupervised and supervised classification, from spectral information alone with data from 244 training sites. Remaining cover classes were identified from the spectral data plus other ancillary information including, a diked area mask, digital elevation data, digital orthoquad photographs, aerial photographs, and local knowledge (Garono et al., 2003b).

\begin{tabular}{|c|c|}
\hline TM2000 Cover Classes & Area (ha) \\
\hline Herbaceous Wetland - Tidal & $6,127.7$ \\
\hline Herbaceous Wetland - Diked & $16,680.4$ \\
\hline Herbaceous Wetland - Non-tidal & 906.9 \\
\hline Herbaceous Upland & $4,619.6$ \\
\hline Shrub-Scrub Wetland - Tidal & $2,973.1$ \\
\hline Shrub-Scrub Wetland - Diked & $3,042.0$ \\
\hline Shrub-Scrub Wetland - Non-tidal & 383.2 \\
\hline Shrub-Scrub Upland & $2,830.2$ \\
\hline Mud & $2,954.3$ \\
\hline Sand & $4,380.0$ \\
\hline Deciduous Forest Wetland - Tidal & $1,697.2$ \\
\hline Deciduous Forest Wetland - Diked & $2,781.5$ \\
\hline Deciduous Forest Wetland - Non-tidal & 176.5 \\
\hline Deciduous Forest Upland & $5,619.8$ \\
\hline Coniferous Forest Wetland - Tidal & $1,278.7$ \\
\hline Coniferous Forest Wetland - Diked & 318.9 \\
\hline Coniferous Forest Wetland - Non-tidal & 157.8 \\
\hline Coniferous Forest Upland & $5,659.8$ \\
\hline Mixed Forest Wetland - Tidal & 170.2 \\
\hline Mixed Forest Wetland - Diked & 99.0 \\
\hline Mixed Forest Wetland - Non-tidal & 30.3 \\
\hline Mixed Forest Upland & $2,134.4$ \\
\hline Water & $41,630.5$ \\
\hline Urban & $5,051.3$ \\
\hline Clouds/Shadows & 187.5 \\
\hline Other & 411.6 \\
\hline
\end{tabular}




\section{Classification Methods}

Both the TM1992 and TM2000 datasets were classified using an iterative classification approach. The C-CAP protocol was used to interpret land cover classes from one Landsat TM scene for creation of the TM1992 data set (NOAA Coastal Services Center, 1997). The TM2000 data set was created by Earth Design Consultants, Inc. (Garono et al., 2003b). Both data sets were classified using ERDAS Imagine image analysis software.

The TM1992 data set was classified using an iterative approach that first focused on separating major cover class categories (e.g., water, forest, developed) using a supervised classification technique. Through field work with knowledgeable wetland ecologists, numerous individual sites were chosen as training sites for the land cover classification. Next, each major category was isolated by masking out all other major categories, and an iterative unsupervised classification was performed on the isolated major category. This method of running unsupervised classification on isolated major classes allowed the multispectral properties of the isolated class to be classified into smaller groups, known as spectral clusters, using user specified criteria. A cover class was then assigned to each spectral cluster using ancillary data sets consisting mostly of field measurements. The final classification labels (cover classes) were assigned to the spectral clusters after several iterations of the unsupervised classification. The classification was further refined using ancillary data such as USGS maps, county marsh inventories, and National Wetland Inventory data. If the land cover class information could not be determined spectrally, the raster cells were coded to a land cover class through visual interpretation of the data available. Finally, a $3 \times 3$ pixel majority class filter was run over the final classified image to reclass errant pixels (NOAA Coastal Services Center, 1997).

Unlike the TM1992 classification, which started with a supervised classification, classification of the TM2000 data set began with an unsupervised classification. The initial unsupervised classification was used to separate the data into several major cover classes. Following this initial step, additional unsupervised classifications were run on each of these major classes individually to further separate them. Numerous unsupervised and supervised classifications were run to cluster and assign land cover classes to the data. Where available, training site data were used to assign land cover classes to the spectral clusters. For cover classes that had no training data, digital orthophoto quadrangles (DOQs), aerial photography and videography, and image interpretation were used to establish the cover classes. In the TM2000 data set, land cover classes were further refined by including the degree to which tidal exchange 
influenced each area using ancillary information as previously described (Garono et al., 2003b).

Prior to conducting the change analysis, both the TM1992 and TM2000 data sets were checked for logical consistency and deemed complete when the classification scheme included all necessary land cover classes and all raster cells were classified. For the TM1992 data set, positional accuracy and precision were inherited directly from the Landsat TM database. The TM1992 scene was georectified and terrain corrected at EROS Data Center in Sioux Falls, South Dakota. The TM1992 data set has a horizontal positional accuracy value with a root mean square error (RMSE) of +/- 0.5 pixels, or +/12.5-m (NOAA Coastal Services Center, 1997). The TM2000 data set has a combined RMSE $X-Y$ positional accuracy of $+/-0.45$ pixels, or $+/-$ 13.5-m (Garono et al., 2003b).

Classification accuracy of the TM1992 classification was assessed by field teams from May 20-23, 1996. Each team visited randomly selected sample locations equipped with a portable color laptop computer linked to a Global Positioning System (GPS). Field teams visited points selected within a twenty pixel buffer area around roads (i.e. 10 pixels on each side of the road) including logging trails. The overall accuracy of the classification was 90.5\%. For the TM2000 classification, Garono et al. (2003b) constructed an accuracy assessment array, from photographs and field visits, to assess both user and producer accuracy. Producer accuracy is seen from the classifier's point of view. It is based on how many tested points were assigned to the proper land cover class. Producer accuracy assessment includes errors of commission, those errors that occur from pixels within the image being assigned to the wrong cover class. User accuracy involves the likelihood that land cover on the ground is actually what the map says it is. Those locations where cover did not correspond to what was indicated on the map were also called errors of omission. The overall classification accuracy of the TM2000 data set was $86.9 \%$.

\section{Data Set Preparation}

For the change analysis, both of the data sets were manipulated to have a common spatial extent and classification scheme (Fig. 1). Although they covered a similar area, each had to be clipped to the extent of the other ensure that the spatial extent was exactly the same. To make the classification schemes similar, a cross-walk table was created to reclassify the data to a new, more general classification scheme (Appendix A). We found it necessary to cross-walk the classification schemes of the two data sets because there was not a one-to-one correspondence between the cover classes. As previously mentioned, cross-walking limits the comparisons that can be made; specifically, we aggregated the coniferous and deciduous forested wetland classes (from 
the TM2000 data set) into a single forested wetland class because the TM1992 data set did not distinguish between those forested classes.

Before the cross-walk table was used to reclassify the datasets, the TM1992 data set was altered to better match the TM2000 data set. This was necessary because the TM1992 data set identified many CRE island areas as uplands. Many of these islands are known to be periodically inundated by the tides and thus, were considered to be wetlands in the TM2000 data set. Therefore, we applied the same GIS mask to the TM1992 data set as was applied to the TM2000 data set. The mask separated many land cover classes into three types, based on the degree of tidal influence: (1) diked, (2) tidal and (3) nontidal. Using the mask, we identified areas that would be tidally-inundated (i.e., wetlands) had they not been diked. The upland areas were all areas not meeting the criteria established in the mask (see Garono et al. (2003b)).

The effect of the application of the GIS mask on the TM1992 data set compared to the TM2000 data set is shown in Figure 3. Figure 3 (left box) shows that without the application of the mask to identify the diked areas, tidally influenced areas and upland areas, the upland categories in the C-CAP data set (TM1992) were over represented compared to the same area in the TM2000 data set (Figure 3: right box). In the example in Figure 3 (center box), the amount of area in Cultivated Land and Grassland classes (yellow) significantly decreased when the mask was applied. The outcome was that the classification of TM1992 more closely matched the classification of TM2000, resulting in a more accurate change analysis.

\section{Change Analysis Methods}

To analyze change from one data set to the other, each raster cell from the TM1992 data set was compared to the corresponding cell in the TM2000 data set by running a crosstabulation in a geographic information system (GIS). This procedure created a new map showing the initial value of each cell (TM1992 land cover class) and the final value for each cell (TM2000 land cover class). At the same time, a change matrix was created with the TM1992 data in the rows and the TM2000 data in the columns. The "CROSSTAB" function was used in Idrisi Kilimanjaro GIS software to create the change map and matrix. See the Change Analysis section in the Introduction for more information on this methodology. 

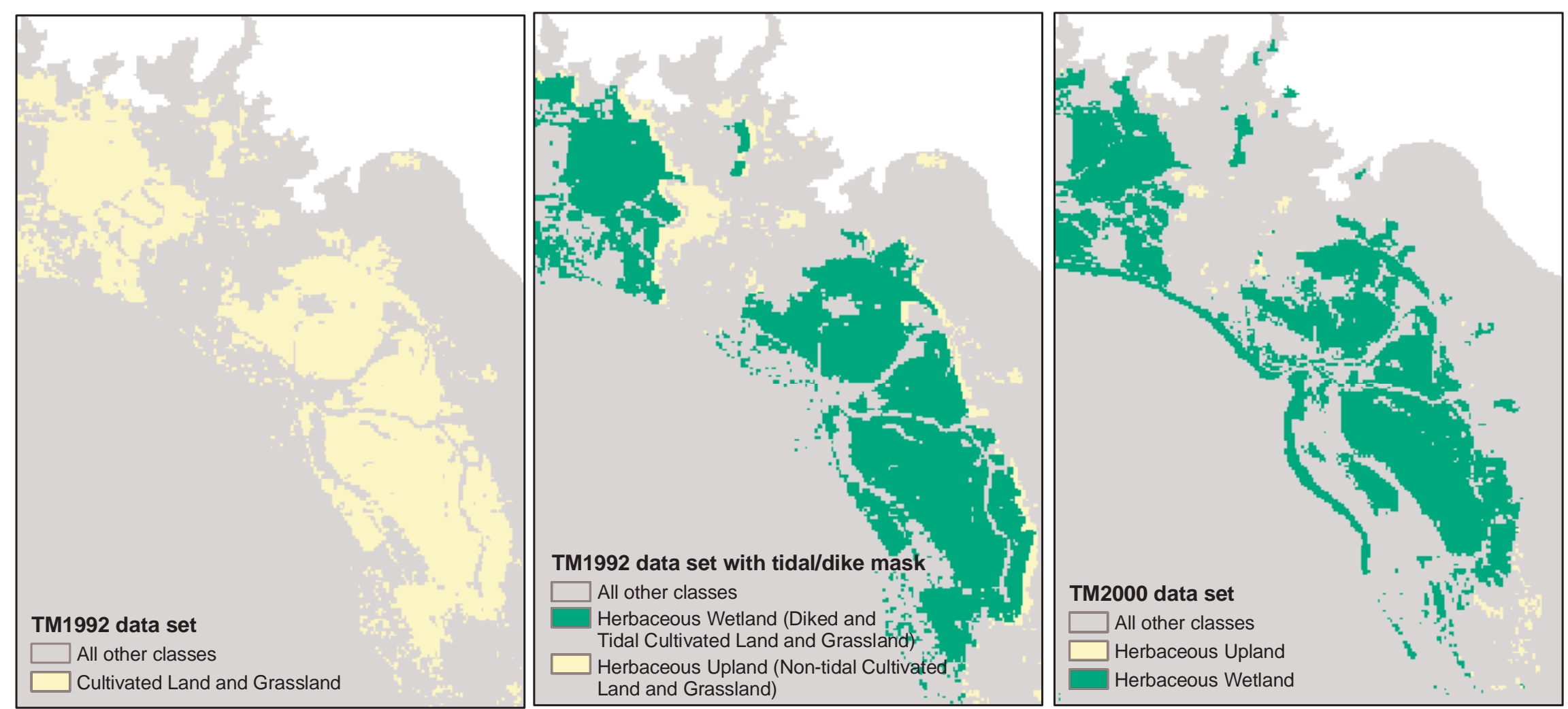

Figure 3: Tidal influence/Diked area mask applied to TM1992. Shown are the TM1992 image without the GIS mask (left), the TM1992 with the GIS mask (center), and TM2000 (right). Yellow represents upland areas, green represents wetland areas, and gray represents all other data classes. The application of the GIS mask to the TM1992 data set make the TM1992 and TM2000 data sets more comparable prior to conducting a change analysis (see text for details). 


\section{RESULTS}

Wetland vegetation dominated the CRE estuary and floodplain in 1992 accounting for $\sim 31 \%$ of the area, aside from deep water which accounted for $\sim 37 \%$ of the land cover (Table 3). Of this, herbaceous wetland accounted for over $18 \%$, with shrub-scrub wetland accounting for $\sim 9 \%$ and forested wetland $4 \%$. Upland cover classes were also common accounting for $18.7 \%$ of the area. Shrub-scrub upland dominated the upland areas with almost $8 \%$ of the total land cover, as compared to much lower land cover totals for herbaceous upland (2.4\%), and the forested upland classes of deciduous $(1.0 \%)$, coniferous $(3.4 \%)$, and mixed $(4.1 \%)$. Urban areas accounted for $5.2 \%$ of the land cover, and unconsolidated shore accounted for $\sim 8 \%$ (Table 3).

\begin{tabular}{|c|c|c|}
\hline Cross-walked Land Cover Class & TM1992 (ha) & $\%$ of Total \\
\hline Herbaceous Wetland & $20,277.2$ & $18.1 \%$ \\
\hline Shrub-Scrub Wetland & $10,028.8$ & $8.9 \%$ \\
\hline Forested Wetland & $4,492.8$ & $4.0 \%$ \\
\hline Herbaceous Upland & $2,658.2$ & $2.4 \%$ \\
\hline Shrub-Scrub Upland & $8,765.4$ & $7.8 \%$ \\
\hline Deciduous Forest Upland & $1,063.2$ & $1.0 \%$ \\
\hline Coniferous Forest Upland & $3,785.7$ & $3.4 \%$ \\
\hline Mixed Forest Upland & $4,614.8$ & $4.1 \%$ \\
\hline Unconsolidated Shore & $9,190.1$ & $8.2 \%$ \\
\hline Urban & $5,841.1$ & $5.2 \%$ \\
\hline Water & $41,585.1$ & $37.0 \%$ \\
\hline
\end{tabular}

We summarized land cover classes over the same area from the TM2000 data and observed similar patterns. Much of the land cover was dominated by wetland ( 33\%), with herbaceous wetland ( 21\%) occurring as the most common cover class following the water class (Table 4). Shrub-scrub wetland (5.7\%) and forested wetland ( $6 \%)$ also accounted for a significant portion of the total land cover. The upland classes of herbaceous $(\sim 4 \%)$, shrub-scrub $(2.5 \%)$, deciduous forest $(5 \%)$, coniferous forest $(5 \%)$, and mixed forest $(1.9 \%)$ accounted for $\sim 18.5 \%$ of the total land cover in the study area, although none of the upland classes alone stood out as a significant portion of the land cover. Urban area covered $4.5 \%$ of the total study area, and unconsolidated shore, including mud and sand, accounted for $\sim 6.5 \%$. A land cover class termed "Other" was 
added to the TM2000 classification and consisted of clouds and other anomalies in the satellite imagery present in the original TM2000 data set. This land cover class accounted for $\sim 0.5 \%$ of the total land cover in the study area (Table 4 ).

\begin{tabular}{|c|c|c|}
\hline \multicolumn{3}{|c|}{$\begin{array}{l}\text { Table 4. Area (ha) for cross-walked cover land cover classes for the EDC } \\
\text { TM2000 classified data set. Also shown is the percent of total area in each } \\
\text { land cover class. }\end{array}$} \\
\hline Cross-walked Land Cover Class & TM2000 (ha) & $\%$ of Total \\
\hline Herbaceous Wetland & $23,715.0$ & $21.1 \%$ \\
\hline Shrub-Scrub Wetland & $6,398.3$ & $5.7 \%$ \\
\hline Forested Wetland & $6,710.0$ & $6.0 \%$ \\
\hline Herbaceous Upland & $4,619.6$ & $4.1 \%$ \\
\hline Shrub-Scrub Upland & $2,830.2$ & $2.5 \%$ \\
\hline Deciduous Forest Upland & $5,619.8$ & $5.0 \%$ \\
\hline Coniferous Forest Upland & $5,659.8$ & $5.0 \%$ \\
\hline Mixed Forest Upland & $2,134.4$ & $1.9 \%$ \\
\hline Unconsolidated Shore & $7,334.3$ & $6.5 \%$ \\
\hline Urban & $5,051.3$ & $4.5 \%$ \\
\hline Water & $41,630.5$ & $37.0 \%$ \\
\hline Other & 599.0 & $0.5 \%$ \\
\hline
\end{tabular}

As previously mentioned, we constructed a GIS mask showing the diked areas because we were interested in identifying wetland areas that were either tidally influenced, diked, or non-tidal. Interestingly, we found that diked areas accounted for $\sim 22,900$-ha of the total 112,302-ha ( 20\%) study area (Fig. 1).

Table 5 shows the results of the change analysis. As we expected, there was little change in the water cover class. We found that the herbaceous wetland and forested wetland cover classes increased in the Columbia River estuary floodplain between 1992 and 2000: there was a 17\% increase in herbaceous wetland cover and a $49 \%$ increase in forested wetland cover. Unfortunately, we were not able to determine if this increase was in coniferous or deciduous wetland forested areas because these classes were identified in the TM1992 data set. We found that there was a $-36.2 \%$ loss in wetland shrub-scrub cover classes (Table 5). We also found that there was a $-20.2 \%$ loss in unconsolidated shore, and a $-13.5 \%$ decrease in the urban cover classes (Table 5). The decrease in the urban cover class was unexpected and may be the result of a more 
accurate classification of the TM2000 than in the TM1992 data set, rather than a true decrease in urban areas (see the discussion below).

We found change in the upland cover classes, as well. Herbaceous upland increased approximately 74\%, while shrub-scrub upland decreased about $-68 \%$ (Table 5). Coniferous forest upland increased by almost 50\%, and the area of mixed forest upland was more than cut in half from 1992 to 2000. Deciduous forest upland had the greatest gain in area from 1992 to 2000 of all of the cover classes, with more than a four-fold increase in area. The "other" class increased from no data classified in this class in 1992 to almost 600 hectares in area in 2000. Because this class did not exist in the 1992 data set, the percent change over time cannot be calculated. However, with the use of the change matrix, it is possible to see what amount of each of the other classes in 1992 were classes as "other" in 2000.

Table 5. Areas (ha) for cross-walked land cover classes for the NOAA C-CAP TM1992 and the EDC TM2000 classified data sets. Also shown is change in area (ha) and change as a percentage of the TM1992 area. Negative numbers indicate loss and positive numbers indicate gain.

\begin{tabular}{|l|r|r|r|c|}
\hline \multicolumn{1}{|c|}{ Cross-walked Land Cover Class } & \multicolumn{1}{c|}{$\begin{array}{c}\text { TM1992 } \\
\text { (ha) }\end{array}$} & \multicolumn{1}{c|}{$\begin{array}{c}\text { TM2000 } \\
\text { (ha) }\end{array}$} & \multicolumn{1}{c|}{$\begin{array}{c}\text { Change } \\
\text { (ha) }\end{array}$} & $\begin{array}{c}\text { Change } \\
\text { \% of 1992 total }\end{array}$ \\
\hline Herbaceous Wetland & $20,277.2$ & $23,715.0$ & $3,437.8$ & $17.0 \%$ \\
\hline Shrub-Scrub Wetland & $10,028.8$ & $6,398.3$ & $-3,630.5$ & $-36.2 \%$ \\
\hline Forested Wetland & $4,492.8$ & $6,710.0$ & $2,217.2$ & $49.4 \%$ \\
\hline Herbaceous Upland & $2,658.2$ & $4,619.6$ & $1,961.5$ & $73.8 \%$ \\
\hline Shrub-Scrub Upland & $8,765.4$ & $2,830.2$ & $-5,935.1$ & $-67.7 \%$ \\
\hline Deciduous Forest Upland & $1,063.2$ & $5,619.8$ & $4,556.6$ & \multicolumn{1}{c|}{$428.6 \%$} \\
\hline Coniferous Forest Upland & $3,785.7$ & $5,659.8$ & $1,874.2$ & \multicolumn{1}{c|}{$49.5 \%$} \\
\hline Mixed Forest Upland & $4,614.8$ & $2,134.4$ & $-2,480.4$ & $-53.7 \%$ \\
\hline Unconsolidated Shore & $9,190.1$ & $7,334.3$ & $-1,855.8$ & $-20.2 \%$ \\
\hline Urban & $5,841.1$ & $5,051.3$ & -789.8 & $-13.5 \%$ \\
\hline Water & $41,585.1$ & $41,630.5$ & 45.4 & \multicolumn{1}{c|}{$0.1 \%$} \\
\hline Other & N/A & 599.0 & 599.0 & \multicolumn{1}{c|}{ N/A } \\
\hline
\end{tabular}

One advantage in using GIS to conduct this type of analysis is that the spatial data sets can be used to identify particular areas where changes have occurred (Fig. 4). The spatial data set produced during the crosstabulation recorded both the "from" and "to" values from each data set in each cell. We performed a simple reclassification of these 
data in Figure 4 to show cells that changed and cells that did not. As we expected, we found that the main channel of the Columbia River shows little change, which is supported by the small amount of change calculated in the water cover class during the crosstabulation $(0.1 \%)$. Interestingly, other areas of the image, other than the main

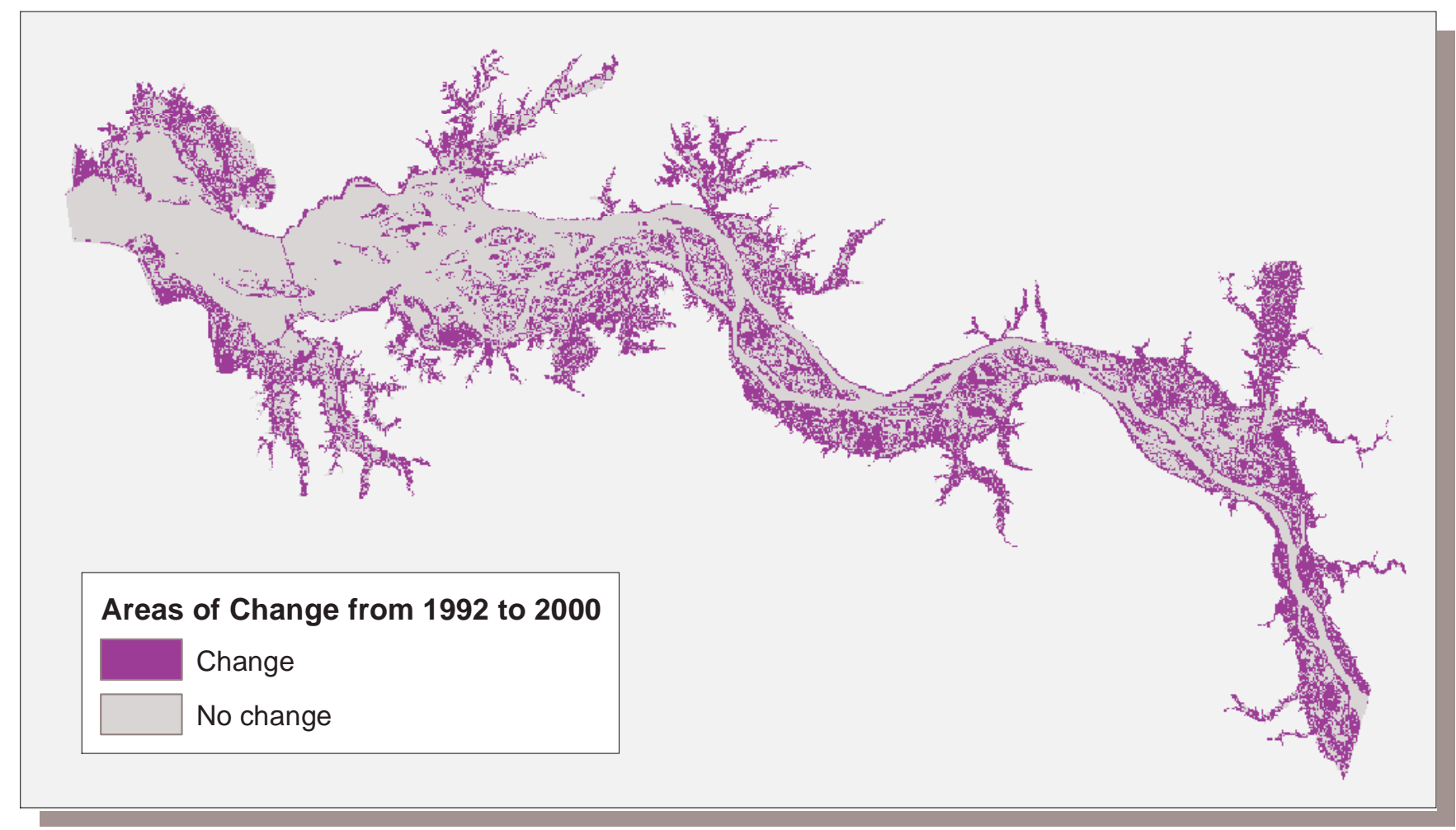

Figure 4: The areas of change from 1992 to 2000. Shown are the areas that have changed (purple) from one cover class to another. Notice the even distribution of changed areas, aside from areas that were and remained water.

river channel, show an even distribution of raster cells that changed from the 1992 to 2000 imagery.

As part of our analysis, we constructed a change matrix to track how land cover classes changed during the eight-year interval between 1992 and 2000. As previously mentioned, this matrix shows the number of cells that remained unchanged during the interval which indicated how dynamic each particular cover class is. For those cells that do change, the matrix tracks the change for each cell giving both the "from" and "to" cover classes. We found the CRE to be a shifting mosaic of land cover types (Table 6). Although there was a net increase of 3,437.8-ha of herbaceous wetlands from 1992 to 2000 (Table 5), only $64.9 \%$ of the area classified as herbaceous wetland from the TM1992 
data set remained as herbaceous wetland in the TM2000 data set (Table 6). This indicated that there were both losses, conversion of herbaceous wetlands to other cover classes, and gains, conversion of other classes to herbaceous wetlands. At this point, it is important to keep in mind that this comparison is dependent on the correct classification of every pixel in each of the two data sets (see Sources of Error).

Of the original 20,277-ha that were classed as herbaceous wetland in 1999, the majority of conversion was to shrub-scrub wetland (12.5\%) and to forested wetland (9\%) in 2000 (Table 6). Using the change matrix it was also possible to see what each current cover class was in the past. For example, of the 23,715-ha that were classed as herbaceous wetland in 2000, 44.4\% had been classified as shrub-scrub wetland, 30.6\% had been classified as forested wetland, and $\sim 24 \%$ had been classified as urban in 1999 . It is unlikely that urban areas were converted to herbaceous wetland during this time interval. Instead, we believe that this change was the result of the way in which the TM1992 image was classified (see discussion below).

For the shrub-scrub wetland areas, only $22.6 \%$ of the area classified as shrub-scrub wetland in 1999 remained in that class in 2000. Although there was a $-36 \%$ decrease in shrub-scrub wetlands from 1999 to 2000 with the greatest loss of area converting to herbaceous wetland $(44.4 \%)$ and forested wetland $(\sim 21 \%), 12.5 \%$ of the area classed as herbaceous wetland and $15.3 \%$ of the area classed as forested wetland in 1999 were converted to shrub-scrub wetland by 2000 .

We found that forested wetlands increased almost 50\% from 1999 to 2000, but only $40.4 \%$ of the original area classed as forested wetland remained forested wetland in 2000. Recall, we were unable to distinguish coniferous from deciduous forests because the TM1992 data only had one forested cover class. The bulk of the increase in area came from herbaceous wetland (9\%) and shrub-scrub wetland (20.9\%). The $60 \%$ conversion from forested wetland to other classes changed primarily to herbaceous wetland (30.6\%), shrub-scrub wetland (15.3\%), and water $(8.9 \%)$.

Of interest is the urban class, which decreased $-13.5 \%$ from 1992 to 2000 . Forty-four percent of the area classified as urban in 1992 remained urban in 2000. According to our results, most of the urban area was converted to herbaceous wetland $(23.9 \%)$ and herbaceous upland $(9.3 \%)$, which is not very likely and is likely the result of the more conservative classification of urban cover in the TM2000 data set (see below). 


\begin{tabular}{lll}
\hline \hline Earth Design Consultants, Inc. & \\
(541) $757-7896$ & http://www.earthdesign.com
\end{tabular}


Table 6. Matrix showing change in multiple land cover classes from 1992 to 2000 for the western region of the Columbia River estuary. This change matrix was derived from two classified Landsat images (see text for details).

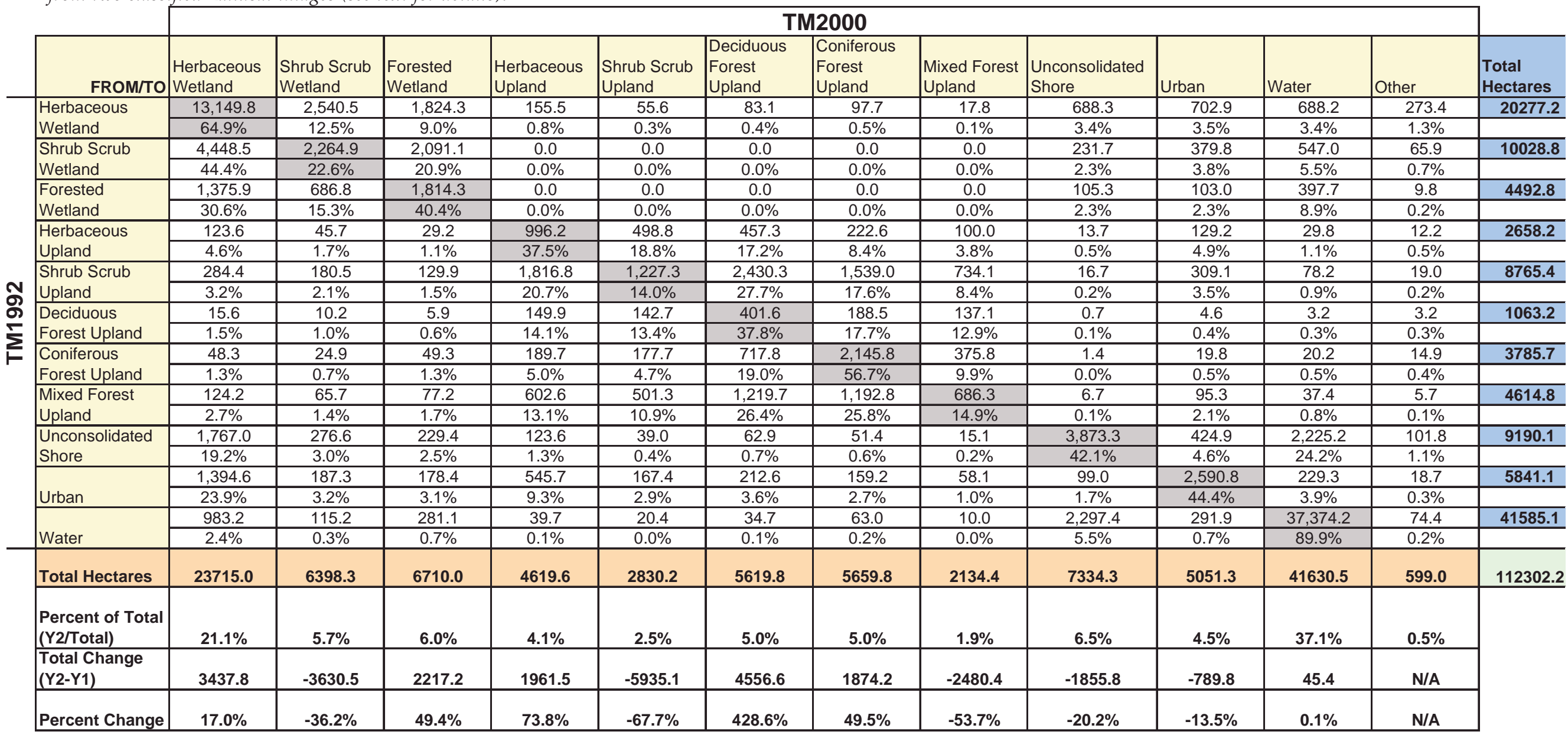




\section{DISCUSSION}

Unexpectedly, we found that there was a $17 \%$ increase in the amount of herbaceous wetland and a 49.4\% increase in forested wetlands from 1992 to 2000; however, the area of shrub-scrub wetlands decreased by $-36.2 \%$ during the same time interval (Table 5). Previous studies have mapped habitats and land cover classes along the lower Columbia River although time intervals, methods, and spatial extents differed from those used in the current study, these other studies have all reported losses in wetland cover classes.

Thomas (1983) compared the geographic extent of five estuarine and two non-estuarine land cover classes, mapped from a series of 1870 1:40,000 navigational charts, with results of a late 1970's land cover mapping project. He interpreted and transferred information from historic navigational charts and modern maps to common 1:24,000 scale maps from the river mouth to the east side of Puget Island. Change in land cover classes along the lower Columbia River estuary were then measured with a planimeter from the 1:24,000 maps. Thomas found that, in general, there was a $-24 \%$ loss of tidal wetland area of the lower estuary. Significant losses also occurred in the areal extent of 'tidal swamps' (-77\%), 'swamps and marshes' (-65\%), and 'deep and medium depth water' $(-16 \%)$ cover classes and there was an increase in the area of the 'shallow and flats' $(+10 \%)$ class. Thomas examined trends in habitat change for several regions within his study area. Although losses in 'deep water', 'medium depth', 'shallows/flats', 'tidal marshes' and 'tidal swamps' exceeded gains, he did report gains (largely from colonization of dredge material and as a result of materials deposited due to jetty construction) in tidal marshes, ranging from $6.8 \%$ to $145.2 \%$, at the Mouth, Gray's Bay, and Cathlamet Bay.

Thomas' 1983 study was later extended from Puget Island to the Bonneville Dam by Graves et al. (1995) using a slightly different methodology. Graves et al. (1995) reported similar losses in wetland cover classes during the period of 1880 to 1991 where wetland marshes decreased in area by $\sim 20 \%$ and forested wetlands decreased by $\sim-10 \%$. Agricultural and urban cover classes showed the largest increases in area, $\sim 20 \%$ and $\sim 8 \%$, respectively.

More recently, Allen (1999) generated GIS polygon layers from aerial photographs taken along the lower Columbia River in 1948, 1961, 1973, 1983 and 1991; photographs (black and white) were taken from August to November and ranged in scale from 
1:12,000 to $1: 48,000$. Using photointerpretation techniques, he mapped 18 cover classes from areas greater than 1-ha in size from 1,750 photographs within a 3-km corridor (whenever possible) from the mouth to the Bonneville Dam. Allen used two classification schemes. The first (based on Anderson (1976)) identified land cover and the second (Cowardin et al., 1979) identified wetland types. Habitat cover classes were transferred from photographic stereo pairs to a Mylar overlay: the scale of each Mylar overlay was adjusted to 1:24,000 by visually superimposing them onto a 7.5' USGS. topographic quadrangle. Two hundred and four, classified polygons were digitized from the 7.5' Mylar overlays by the U.S. Army COE. Although Allen reported that he field checked features identified in the 1991 photographs for accuracy, he did not report the spatial nor classification accuracy of his data layers. By comparing this temporal sequence of photos, he was able to measure change. Allen found that the "wetland habitats which were once contiguously draped upon the linear features of the river are decreasing in size and becoming fragmented." He found that during the period of 1948 to 1991 , there was a $-25 \%$ decrease in the area of estuarine wetland cover classes, a $1 \%$ increase in the area of the riverine tidal wetland cover class and a $-37 \%$ decrease in the riverine lower perennial wetland cover class over his study area. Most of the wetland losses were attributed to "in-water activities", such as channelization, and to urbanization.

Perhaps most relevant to Phase I of this study was a study completed in 1992 by NOAA as part of its Coastal Change Analysis Program (C-CAP). The C-CAP study compared two Landsat Thematic Mapper (TM) satellite images, from 1989 and 1992, to measure change along the lower Columbia River. The 1992 imagery was classified using C-CAP protocols (Dobson et al., 1995) and candidate change pixels were identified through band differencing. Candidate pixels were then reclassified to derive the 1989 landcover database. The C-CAP study found that the area (area is larger in spatial extent than the current study and includes Willapa Bay) is dominated by evergreen forested lands $(<50 \%$ of the area) and that forest transitions dominated the change in the landscape: over 59,000-ha of forested areas were lost from 1988 to 1993 (Note: there are two dates given for the Columbia River C-CAP study and we made the assumption that the 1992/93 data sets were equivalent: Table 7). C-CAP describes forest transitions as "a cyclic silviculture process, which involves the harvest and reforestation of predominantly evergreen and mixed forest stands." (online http://www.csc.noaa.gov/crs/lca/pdf/or_cr89-93_CR.pdf).

Although the C-CAP study was not focused on wetlands in the CRE, it documents a loss of 765.3-ha of wetlands in their study area (Table 7). Although the loss of wetlands 
in each of the wetland cover classes greatly exceeds the gains, there were small gains in the area of emergent marshes (Table 7).

Previous studies have overwhelmingly reported losses in wetland cover classes along the CRE during different time intervals (Thomas, 1983; Graves et al., 1995; Allen, 1999). Our study results confirm that thee has been a dramatic loss in shrub-scrub wetlands (Table 6) but that forested and herbaceous wetlands have increased from 1992 to 2000 (Table 5,6$)$. Furthermore, we found a $-13.5 \%$ decrease in the urban cover class. How can these results be interpreted?

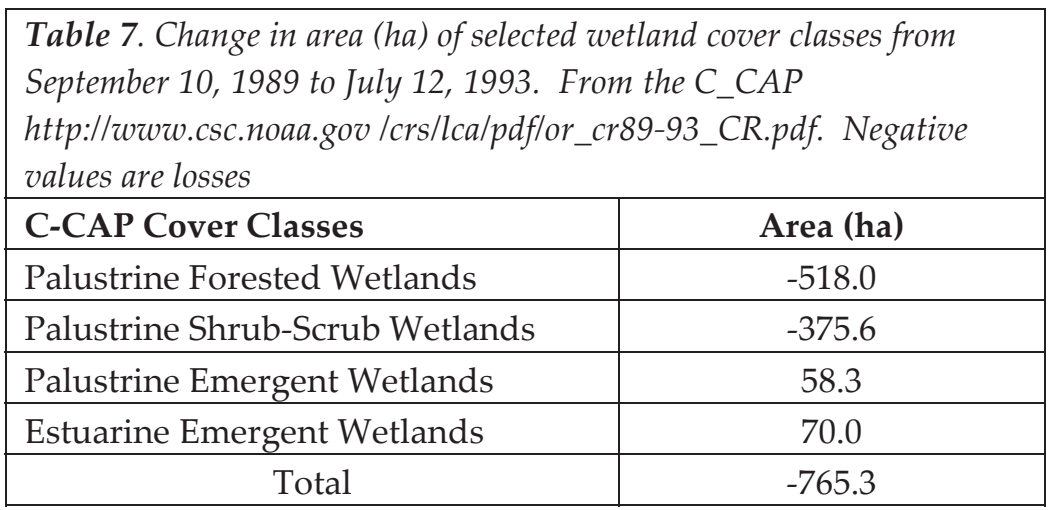

\section{Interpreting the Cover Classes in the 1992-2000 Analysis}

In this study, we used GIS to interpret results. In GIS, we were able to view changes in land cover within areas with which we were familiar. We were most interested in determining if the change that was detected has biological meaning.

The definition of the water cover class was the same in both image sets and perhaps the least ambiguous when it came to cross-walking the cover classes; therefore, we expected the water cover class to be relatively unchanged during the 1992 to 2000 interval. Indeed, this was the case. As we expected, we found the least amount of change $(0.1 \%)$ in the water class during the 8-year interval (Table 6). Of interest, is that while the total area classified as water only varied $0.1 \%$ of the total area, more than $10 \%$ of the area classified as water in the TM1992 data set ended up in another classes (mainly unconsolidated shore and herbaceous wetland) in the TM2000 (Table 6). This is possible considering that fluctuating water levels and fringe pixels may have moved 
between cover classes in the TM1992 and TM2000 data sets, especially from the cover classes where the change was observed.

The $-13.5 \%$ decrease in the urban cover class was unexpected. We expected that the Urban cover classes in the two date sets to be nearly the same: the TM1992 High and Low Intensity Developed classes were combined into one class before being compared with the urban cover class in the TM2000 data set (Appendix A). If there were to be a change, we expected there to be an increase in the urban cover class. Upon closer inspection, we found that although the urban areas mapped in both data sets were similar in spatial extent, the TM2000 data set seemed to better discriminate between the urban areas (buildings and roads) and vegetated areas within and surrounding the urban areas (Fig. 5) than the TM1992 data set. This is true in particular when comparing the roads (classified as Urban) within the two data sets.

The more generally defined urban areas in the TM1992 data set may be explained by the application of a $3 \times 3$ pixel majority moving window filter (this filter was not used in producing the TM2000 data set). A moving window filter was used to remove 'salt and pepper' or errant pixels from the classified image. Figure 5 compares the relatively solid block of Urban pixels from the TM1992 (Fig. 5 left) with the speckled block of Urban pixels in the TM2000 data set (Fig. 5 right). We believe that the loss in the Urban cover class is due the more accurate classification of urban areas (reported as $100 \%$ accurately identified in Garono et al. (2003b)) in the TM2000 data set. Support also comes from Table 6 where we reported that more than $9.0 \%$ of the area that was classified as Urban in 1999 became herbaceous upland in 2000 suggesting that the TM2000 classification correctly identified the lawns and parks common in urban areas.

We found a $-20.2 \%$ loss in the unconsolidated shore cover class. Cells from the TM1992 unconsolidated shore class changed to herbaceous wetland $(19.2 \%)$ and water $(24.2 \%)$ in the TM2000 classification (Table 6). These transformations can be explained by the daily fluctuations in the water level in the CRE; the

We also reported that there was a $49.4 \%$ increase in the forested wetland cover class (Table 6). Areas classified as herbaceous wetland (9.0\%) and shrub-scrub wetland (20.9\%) in the TM1992 data set were reclassified as forested wetland in the TM2000 data set. Approximately $40 \%$ of the area remained unchanged and was classified as forested wetland in both data sets. We used the GIS to examine areas that we were familiar with from our ground surveys. We found that areas around Clatskanie, and on Puget, 

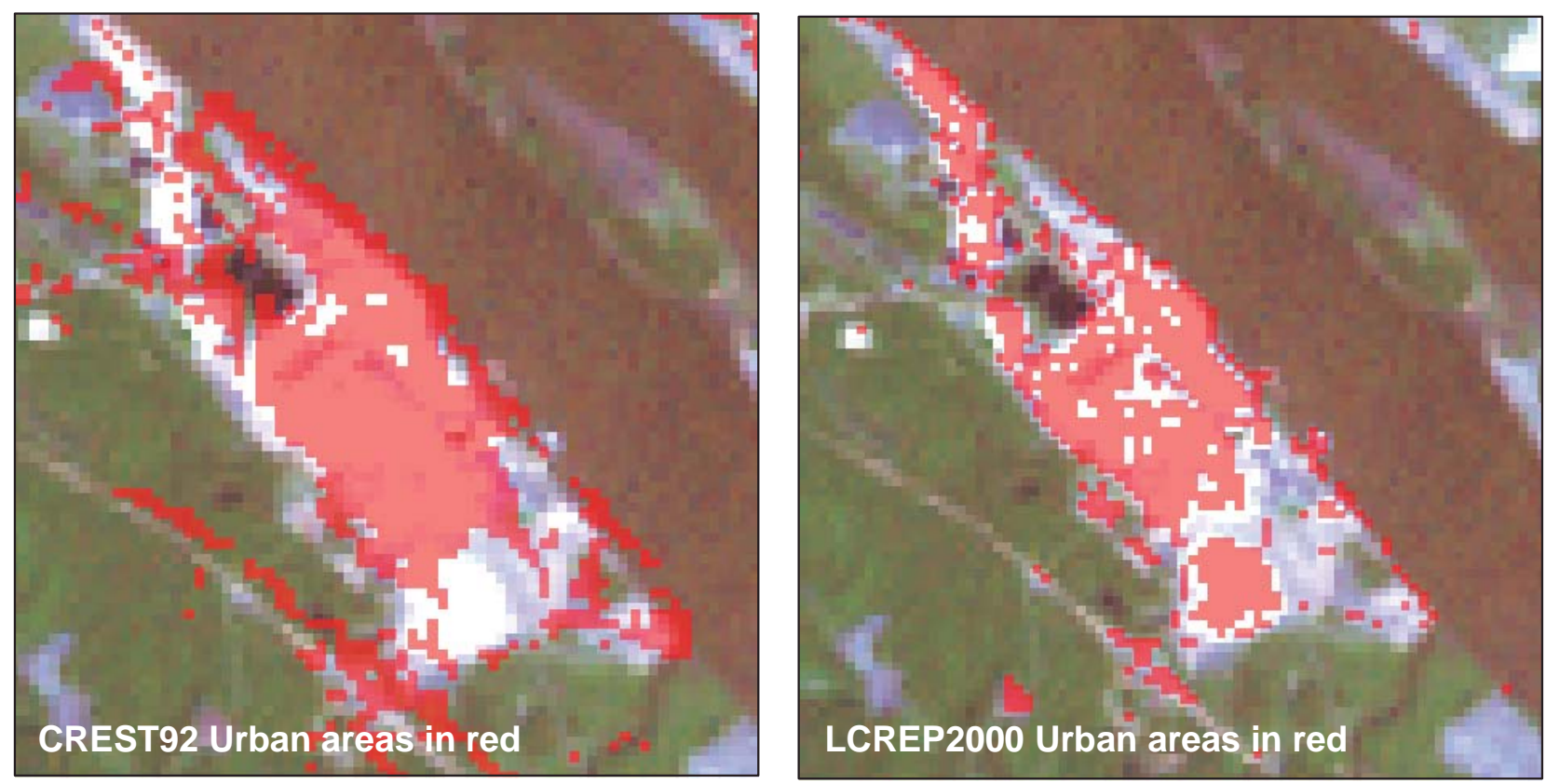

Figure 5: Comparison of urban cover class (red) from TM1992 (left) and TM2000 data sets (right).

Classified data are shown against the unclassified TM2000 scene. The TM1992 data set was subjected to a 3 X 3 pixel majority filter which may have reclassified nearby herbaceous upland and forested upland pixels as urban thereby overestimating the amount of urban cover. Notice the displacement of the TM1992 from the TM2000 background image.

Karlson, and Sauvie Islands that were classified as herbaceous wetland in the TM1992 data set were classified as forested wetlands in the TM2000. Many of these were areas where hybrid poplars had been planted in diked areas. Hybrid poplars would be included in the forested wetland cover class since diked areas were considered to be wetland areas in this study (Appendix A).

We reported a $428.6 \%$ increase in deciduous forest uplands. In Table 6 we show that cover classes identified as shrub-scrub upland (27.7\%), mixed forest upland $(26.4 \%)$, coniferous forest upland (19.0\%), and herbaceous upland $(17.2 \%)$ in the TM1992 were classified as deciduous forest upland in the TM2000 data set. Using the GIS we found that relatively large areas in the Upper Chinook and West Fork/ Skamokawa watersheds, and Brownsmead were areas where shrub-scrub upland transitioned into deciduous upland. This observation is consistent with normal successional transitions.

Results from this study underscored many of the trends in the changing landscape mosaic of the CRE. Most of the trends observed were consistent with our knowledge of the study area. We found that although there was a great deal of movement from one 
cover class to another in general, the area tends to remain within either the wetland or the upland classes (the average area retained in each class from 1992 to 2000 was $42.3 \%$, median of $40.4 \%$ ). Moreover, cells classed as wetland classes generally move to or from other wetland classes, cells classed as upland classes move to or from other upland classes. This suggests that the distinction between wetlands and non-wetlands, accomplished largely with the GIS mask, was accurate.

\section{Recommendations}

1) Both of the data sets used in this study were the result of very accurate classifications. Positional accuracies were similar and also very good for both data sets. The classifications were very similar when considered separately. Differences between the areas measured in each study (following application of the GIS mask and cover class cross-walking) for each cover class only ranged between $0.0 \%$ to $5.3 \%$ (Tables 3 and 4). Nevertheless, we still found the offset features to be problematic. For example, Figures 5 and 6 illustrate the offset in georeferencing the TM1992 and TM2000 data sets. If there were no georeferencing offset, the road would line up better in Figure 5 and the majority of the image in Figure 6 would be purple indicating that there is a complete overlap. Instead, Figure 6 shows large amount of red and blue, indicating that the layers do not match spatially.

The consequence of this slight offset was that there was not a one-to-one correspondence of cells (pixels) between the two data sets. Changes in small patches, long linear features and fringes of larger patches would be exaggerated. We found this to be the case with the urban cover class and it undoubtedly influenced our other comparisons.

For future change analyses (based on satellite data), we recommend handling both data sets using identical methods, similar to the techniques used by the C-CAP program. For satellite data, a band differencing approach could be the most effective. First, one image could be exactly georeferenced to the second image thereby eliminating the positional shift described above. Second, it would not be necessary to classify both images. Instead, one image could be classified and only areas of change classified in the second image. Finally, if image filters were to be used, filters could be applied equally to both images unlike the two images used in this study.

However, if the change analysis were to be performed with imagery that does not have consistent geopositioning, we recommend using the procedure undertaken in this study. Compact Airborne Spectrographic Imagery (CASI) imagery collected as 
part of the Estuary Partnership's habitat mapping project (Garono et al., 2003a) is better suited for the change analysis procedures used in the current study because of the variable spatial accuracy. In any case, we recommend that both data sets be classified using identical classification schemes and processing methods.

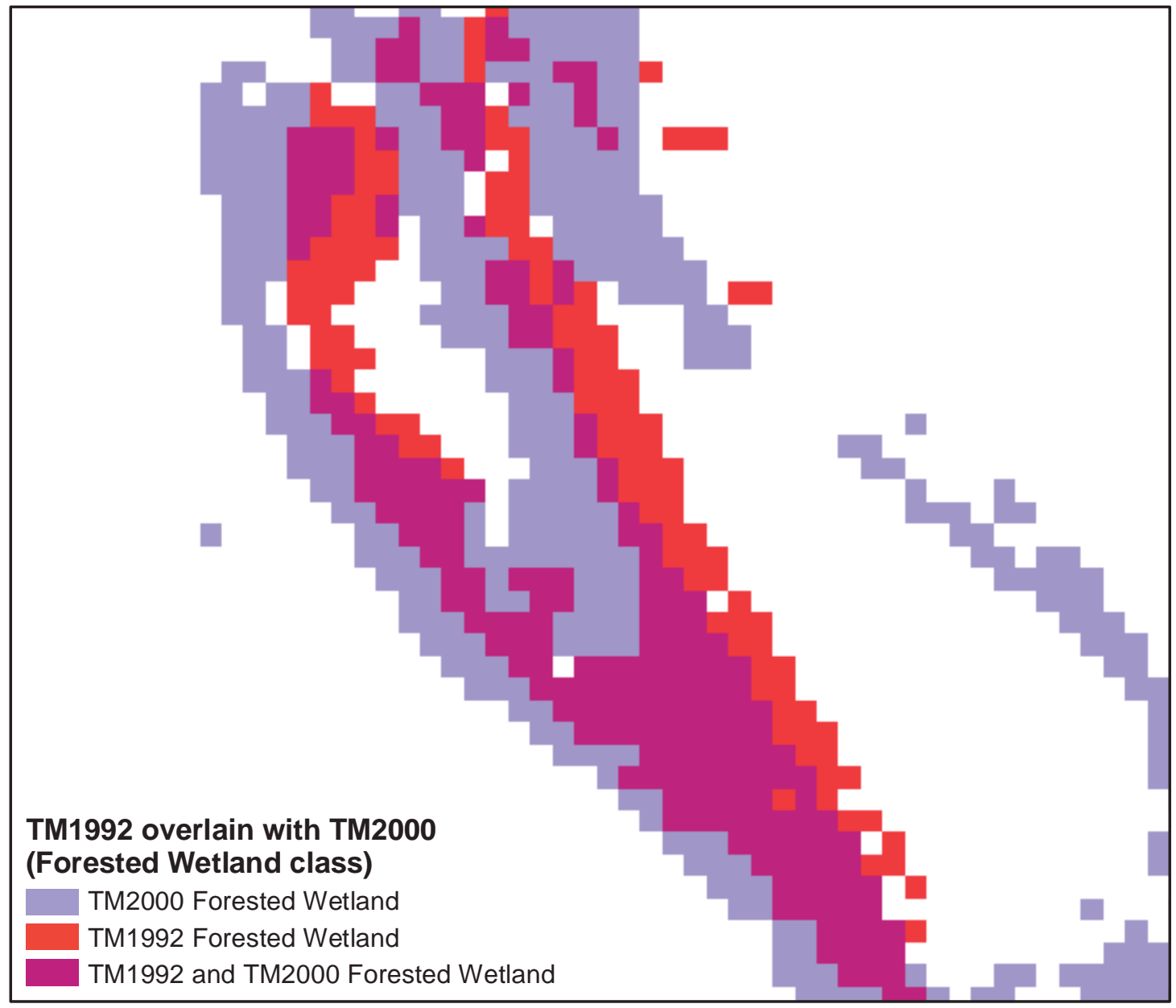

Figure 6: Georeferencing offset. Shown here are the forested areas from the TM1992 image (red) and the TM2000 image (blue). If the position of the images matched up better, the area of overlap (purple) would be greater. This offset influenced the results of this study (see text).

2) We recommend using these study results to formulate and conservation / restoration plan. Results of this change analysis can be used to locate 'high quality' areas (forested, wetlands, etc.) that have not changed over time. Habitat quality can be determined from fish use data. Since these study results exist within a spatial data 
set, other criteria could be used to locate and prioritize unchanging areas such as, size, relative position in the estuary or landscape, ownership, distance from similar areas, etc. In addition, spatial correlations could be run to determine what factors, if any, were associated with the areas identified as 'high quality.' If such factors were found, the relationships between environmental factors and habitat quality could be used to establish restoration criteria.

We also recommend using the newly created diked area GIS mask to evaluate sites for conservation and restoration. The diked mask was created using available information and local knowledge. This spatial data set comprehensively maps many habitat cover classes that are influenced by dikes. By considering past and present land cover within at these areas, sites could be ranked on the basis of their stability over time.

3) Develop a wetland restoration prioritization model similar to the one developed by Allen (1999). In his model, Allen ranked sites as low, moderate or high based on a site's potential for restoration. In his prioritization scheme, low potential would be those wetlands identified in the 'from' that were less than 1-ha in size, or, sites identified as wetlands in the 'from' data set and 'urban' in the 'to' data set, or that became submerged. Moderate potential would be those wetlands between 1-ha and 2.5-ha in size, and did not appear as Urban in the 'to' data set; although areas of moderate potential could be areas that appeared as agricultural lands in the 'to' data set. Finally, high potential for restoration includes those wetlands $>2.5$-ha and not appearing as agricultural land in the 'to' data set.

Other criteria could be added within a GIS framework. And, Allen's rule-based method could be adapted for forested areas, as well.

4) Use the results of this study and the results of the habitat mapping project to identify habitat cover types of particular interest such as tidal swamps. Evaluate these areas for conservation.

5) Consider using the results of this study and other available information to document changes features not captured in this analysis, e.g., changes in shoreline development, tidal channel sinuosity, impervious cover, etc.

6) Repeat this study using newly acquired Landsat satellite data or use the results of the C-CAP program in 5-10 years. For more detailed information, consider collecting 
CASI data in 2005 to conduct a 5 year change analysis for areas covered in the 2000/01 CASI flights.

\section{ACKNOWLEDGEMENTS}

We would like to acknowledge the support of the Lower Columbia Estuary Partnership and its collaborators. In addition, we are indebted to the UW and Estuary Partnership staff and a multitude of volunteers who contributed to this project. 


\section{LITERATURE CITED}

Allen, T. H. 1999. Areal distribution, change and restoration potential of wetlands within the lower Columbia River riparian zone, 1948-1991. Corvallis, OR, Oregon State University.

Anderson, J. R., E. E. Hardy, J. T. Roach and R. E. Witmer. 1975. A land use and land cover classification system for use with remote sensor data, US Geological Survey Professional Paper: 964.

Anderson, J. R., E. E. Hardy, J. T. Roach and R. E. Witmer. 1976. A land use and land cover classification system for use with remote sensor data. Reston, VA, US Geological Survey: 964.

Burkhalter, S. 2003. NOAA Coastal Remote Sensing Program, Personal Communication.

Cowardin, L. M., V. Carter and E. T. LaRoe. 1979. Classification of Wetlands and Deepwater Habitats of the United States. Washington, D.C., U.S. Department of the Interior, Fish and Wildlife Service, Office of Biological Services.

Dobson, J. E., E. A. Bright, R. L. Ferguson, D. W. Field, L. L. Wood, K. D. Haddad, H. Iredale, J. R. Jensen, V. V. Klemas, R. J. Orth and J. P. Thomas. 1995. NOAA Coastal Change Analysis Program (C-CAP): Guidance for Regional Implementation, NOAA Technical Report NMFS 123, Department of Commerce: 139.

Garono, R. J., R. R. Robinson and C. A. Simenstad. 2003a. Estuarine Landcover Along the Lower Columbia River Estuary Determined from Compact Airborne Spectrographic Imager (CASI) Imagery. Portland, OR, Lower Columbia River Estuary Partnership: $21+$ Figures \& Appendices. 
Garono, R. J., R. R. Robinson and C. A. Simenstad. 2003b. Estuarine Landcover along the Lower Columbia River Estuary Determined from Landsat 7 ETM+ Imagery. Portland, OR, Lower Columbia River Estuary Partnership: 17.

Graves, J. K., J. A. Christy, P. J. Clinton and P. L. Britz. 1995. Historic habitats of the lower Columbia River. Astoria, OR, Columbia River Estuary Study Taskforce: 14.

Jerrick, N. 1991. The Lower Columbia River Estuary Program Comprehensive Conservation Management Plan: Volume 1. Portland, OR, The Lower Columbia River Estuary Program: 222.

Klemas, V., J. E. Dobson, R. L. Ferguson and K. D. Haddad. 1993. "A coastal land cover classification system for the NOAA CoastWatch Change Analysis Project." Journal of Coastal Res. 9: 862-872.

NOAA. 1997. Columbia River Estuary Land Cover Change Project. Charleston, SC, NOAA Coastal Services Center.

NOAA Coastal Change Analysis Program. 2003.

NOAA Coastal Services Center. 1997. C-CAP- Changes in Land Cover in the Columbia River Estuary: 1989-1992 (compact disc). NOAA/CSC/1-97/001, CREST92 metadata (CREST92.htm). Charleston, S.C.: US Department of Commerce National Oceanic and Atmospheric Administration Coastal Services Center.

Thomas, D. W. 1980. Study of the intertidal vegetation of the Columbia River Estuary. Astoria, OR, Columbia river Estuary Data Development Program. 
Thomas, D. W. 1983. Changes in Columbia River Estuary Habitat Types over the Past Century. Astoria, OR, Columbia River Estuary Data Development Program, Columbia River Estuary Task Force: $50 \mathrm{pp}$. 


\section{APPENDIX A. CROSSWALK BETWEEN SETS OF CLASSIFIED IMAGERY}

\begin{tabular}{|c|c|c|}
\hline Crosswalk & C-CAP $1992^{1}$ & TM 2000 \\
\hline Unconsolidated Shoreline & $\begin{array}{c}\text { Unconsolidated Shoreline } \\
\text { Bare Land }\end{array}$ & $\begin{array}{l}\text { Mud } \\
\text { Sand }\end{array}$ \\
\hline Herbaceous Wetland & $\begin{array}{c}\text { Palustrine Emergent - Tidal } \\
\text { Palustrine Emergent - Diked } \\
\text { Palustrine Emergent - Non-tidal } \\
\text { Estuarine Emergent - Tidal } \\
\text { Estuarine Emergent - Diked } \\
\text { Estuarine Emergent - Non-tidal } \\
\text { Grassland - Tidal } \\
\text { Grassland - Diked } \\
\text { Cultivated Land - Tidal } \\
\text { Cultivated Land - Diked }\end{array}$ & $\begin{array}{c}\text { Herbaceous Wetland - Tidal } \\
\text { Herbaceous Wetland - Diked } \\
\text { Herbaceous Wetland - Non-tidal }\end{array}$ \\
\hline Shrub-Scrub Wetland & $\begin{array}{c}\text { Palustrine Shrub-Scrub Tidal } \\
\text { Palustrine Shrub-Scrub - Diked } \\
\text { Palustrine Shrub-Scrub - Non- } \\
\text { tidal } \\
\text { Shrub-Scrub - Tidal } \\
\text { Shrub-Scrub - Diked } \\
\end{array}$ & $\begin{array}{c}\text { Shrub-Scrub Wetland - Tidal } \\
\text { Shrub-Scrub Wetland - Diked } \\
\text { Shrub Scrub Wetland - Non-tidal }\end{array}$ \\
\hline Forested Wetland & $\begin{array}{c}\text { Evergreen Forest - Tidal } \\
\text { Evergreen Forest - Diked } \\
\text { Mixed Forest - Tidal } \\
\text { Mixed Forest - Diked } \\
\text { Deciduous Forest - Tidal } \\
\text { Deciduous Forest - Diked } \\
\text { Palustrine Forest - Tidal } \\
\text { Palustrine Forest - Diked } \\
\text { Palustrine Forest - Non-tidal }\end{array}$ & $\begin{array}{c}\text { Deciduous Forest Wetland - Tidal } \\
\text { Deciduous Forest Wetland - Diked } \\
\text { Deciduous Forest Wetland - Non-tidal } \\
\text { Coniferous Forest Wetland - Tidal } \\
\text { Coniferous Forest Wetland - Diked } \\
\text { Coniferous Forest Wetland - Non-Tidal } \\
\text { Mixed Forest Wetland - Tidal } \\
\text { Mixed Forest Wetland - Diked } \\
\text { Mixed Forest Wetland - Non-tidal }\end{array}$ \\
\hline Water & Water & Water \\
\hline Urban & $\begin{array}{l}\text { Developed High Intensity } \\
\text { Developed Low Intensity }\end{array}$ & Urban \\
\hline Other & & $\begin{array}{l}\text { Clouds } \\
\text { Other }\end{array}$ \\
\hline Herbaceous Upland & $\begin{array}{c}\text { Grassland - Non-tidal } \\
\text { Cultivated Land - Non-tidal }\end{array}$ & Herbaceous Upland \\
\hline Shrub-Scrub Upland & Shrub-Scrub - Non-tidal & Shrub-Scrub Upland \\
\hline Deciduous Forest Upland & Deciduous Forest - Non-tidal & Deciduous Forest Upland \\
\hline Coniferous Forest Upland & Evergreen Forest - Non-tidal & Coniferous Forest Upland \\
\hline Mixed Forest Upland & Mixed Forest - Non-tidal & Mixed Forest Upland \\
\hline
\end{tabular}

${ }^{1}$ modified for this study through the use of a GIS layer depicting dikes. 


\section{Appendix B. Description of Classification Scheme}

\begin{tabular}{|c|c|}
\hline Cover Class & Description \\
\hline Unconsolidated Shoreline & $\begin{array}{l}\text { C-CAP: Included the Unconsolidated Shoreline and Bare Land } \\
\text { cover classes. The Unconsolidated Shore class includes all } \\
\text { wetland habitats having three characteristics: (1) unconsolidated } \\
\text { substrates with }<75 \% \text { areal cover of stones, boulders, or bedrock; } \\
\text { (2) <30\% areal cover of vegetation other than pioneering plants; } \\
\text { and (3) any of the following water regimes: irregularly exposed, } \\
\text { regularly flooded, irregularly flooded, seasonally flooded, } \\
\text { temporarily flooded, intermittently flooded, saturated, or } \\
\text { artificially flooded. Bare Land is composed of bare rock, sand, silt, } \\
\text { gravel, or other earthen material with little or no vegetation } \\
\text { regardless of its inherent ability to support life. Vegetation, if } \\
\text { present, is more widely spaced and scrubby than that in the } \\
\text { vegetated categories. } \\
\text { EDC: Included the Mud and Sand cover classes. The 'Sand' cover } \\
\text { class was defined as having 70\% of the area as exposed sand: } \\
\text { exposed sand was identified in aerial photographs and during a } \\
\text { series of site visits. The 'Mud' cover class was defined as having } \\
70 \% \text { of the area as exposed mud: exposed mud was identified in } \\
\text { aerial photographs and during a series of site visits. }\end{array}$ \\
\hline Herbaceous Wetland & $\begin{array}{l}\text { C-CAP: Included the Palustrine and Estuarine Emergent, } \\
\text { Grassland and Cultivated (after application of the GIS mask) } \\
\text { cover classes. The emergent wetland classes are characterized by } \\
\text { erect, rooted, herbaceous hydrophytes (excluding mosses and } \\
\text { lichens) which are present for most of the growing season in most } \\
\text { years. These wetlands are usually dominated by perennial plants. } \\
\text { All water regimes are included. The Grassland category includes } \\
\text { lands covered by natural and managed herbaceous cover. } \\
\text { Agricultural Land is land used primarily for production of food } \\
\text { and fiber. } \\
\text { EDC: Areas dominated by herbaceous vegetation falling within } \\
\text { wet areas defined within the GIS tidal mask. }\end{array}$ \\
\hline Shrub-Scrub Wetland & $\begin{array}{l}\text { C-CAP: Includes Palustrine and Shrub-Scrub cover classes (after } \\
\text { application of the GIS mask). Deciduous Scrub/Shrub includes all } \\
\text { areas having a predominance of shrubs, defined as vegetation } \\
\text { that is }<6 \text { meters ( } 20 \text { feet) in height. The species include true } \\
\text { shrubs, young trees, and trees or shrubs that are small or stunted } \\
\text { because of environmental conditions. }\end{array}$ \\
\hline
\end{tabular}

Earth Design Consultants, Inc.

(541) 757-7896 http://www.earthdesign.com 


\begin{tabular}{|c|c|}
\hline Cover Class & Description \\
\hline & $\begin{array}{l}\text { EDC: Shrub-Scrub classes had }>70 \% \text { shrub (woody vegetation }<8 \\
\text { ft high) cover. }\end{array}$ \\
\hline Forested Wetland & $\begin{array}{l}\text { C-CAP: Includes Evergreen, Mixed, Deciduous, and Palustrine } \\
\text { cover classes (after application of the GIS mask). Deciduous } \\
\text { Forested Wetland is characterized by woody vegetation }>6-\mathrm{m} \text { in } \\
\text { height. Evergreen Forested Wetland is characterized by woody } \\
\text { vegetation > 6-m in height. Mixed Forested Wetland includes all } \\
\text { forested areas where both evergreen and deciduous trees are } \\
\text { growing and neither predominates. All water regimes are } \\
\text { included except subtidal. } \\
\text { EDC: Includes Deciduous, Coniferous and Mixed Forest cover } \\
\text { classes. We defined forested classes as having compositions }> \\
60 \% \text { of conifers or broadleaved vegetation for each respective } \\
\text { cover class. Mixed forest classes had proportions of conifers to } \\
\text { deciduous ranging from } 40 / 60 \text { to } 50 / 50 \text {. }\end{array}$ \\
\hline Water & $\begin{array}{l}\text { C-CAP: Deepwater habitats include environments where surface } \\
\text { water is permanent } \\
\text { EDC: water }\end{array}$ \\
\hline Urban & $\begin{array}{l}\text { C-CAP: Included High and Low density urban cover classes. } \\
\text { Developed Land includes heavily built-up urban centers and } \\
\text { large constructed surfaces in suburban and rural areas with a } \\
\text { variety of different land uses. The High Intensity category } \\
\text { contains areas in which a significant land area is covered by } \\
\text { concrete and asphalt or other constructed materials. Vegetation, if } \\
\text { present, occupies < } 20 \text { per cent of the landscape. Examples of such } \\
\text { areas include apartment buildings, skyscrapers, shopping centers, } \\
\text { factories, industrial complexes, large barns, airport runways, and } \\
\text { interstate highways } \\
\text { EDC: Urban areas were identified from the unclassified imagery, } \\
\text { DOQs and other aerial photography and included buildings, } \\
\text { streets and other infrastructure. }\end{array}$ \\
\hline Other & EDC: Clouds, log rafts, etc. \\
\hline Herbaceous Upland & $\begin{array}{l}\text { C-CAP: Included the Grassland and Cultivated (after application } \\
\text { of the GIS mask) cover classes. The Grassland category includes } \\
\text { lands covered by natural and managed herbaceous cover. } \\
\text { Agricultural Land is land used primarily for production of food } \\
\text { and fiber. } \\
\text { EDC: Areas dominated by herbaceous vegetation falling within } \\
\text { upland areas defined within the GIS tidal mask. }\end{array}$ \\
\hline
\end{tabular}

Earth Design Consultants, Inc.

(541) 757-7896 http://www.earthdesign.com 


\begin{tabular}{|c|c|}
\hline Cover Class & Description \\
\hline Shrub-Scrub Upland & $\begin{array}{l}\text { C-CAP: Shrub-Scrub cover classes (after application of the GIS } \\
\text { mask). This category contains vegetation that is }<6 \text { meters }(20 \\
\text { feet) in height. The species include true shrubs, young trees, and } \\
\text { trees or shrubs that are small or stunted because of environmental } \\
\text { conditions. } \\
\text { EDC: Shrub-Scrub classes had }>70 \% \text { shrub (woody vegetation }<8 \\
\mathrm{ft} \text { high) cover. }\end{array}$ \\
\hline Deciduous Forest Upland & $\begin{array}{l}\text { C-CAP: Deciduous Forested Wetland is characterized by woody } \\
\text { vegetation }>6-\mathrm{m} \text { in height. } \\
\text { EDC: We defined forested classes as having compositions }>60 \% \\
\text { of broadleaved vegetation. }\end{array}$ \\
\hline Coniferous Forest Upland & $\begin{array}{l}\text { C-CAP: Evergreen Forested Wetland is characterized by woody } \\
\text { vegetation }>6-\mathrm{m} \text { in height } \\
\text { EDC: We defined forested classes as having compositions }>60 \% \\
\text { of conifers. }\end{array}$ \\
\hline Mixed Forest Upland & $\begin{array}{l}\text { C-CAP: Mixed Forested Wetland includes all forested areas } \\
\text { where both evergreen and deciduous trees are growing and } \\
\text { neither predominates. } \\
\text { EDC: Mixed forest classes had proportions of conifers to } \\
\text { deciduous ranging from } 40 / 60 \text { to } 50 / 50 \text {. }\end{array}$ \\
\hline
\end{tabular}

